\title{
International Entrepreneurship from Emerging to Developed Markets: an institutional perspective
}

\author{
Nuraddeen Nuhu \\ Universidad de las Américas Puebla, nuraddeen.nuhu@udlap.mx \\ Martin Owens \\ Sheffield Hallam University, m.owens@shu.ac.uk \\ Deirdre McQuillan \\ Technological University Dublin, deirdre.mcquillan@tudublin.ie
}

Follow this and additional works at: https://arrow.tudublin.ie/buschgraart

Part of the Entrepreneurial and Small Business Operations Commons

\section{Recommended Citation}

Nuhu, N.S., Owens, M. and McQuillan, D. (2021), International entrepreneurship from emerging to developed markets: an institutional perspective. International Marketing Review, Vol. ahead-of-print No. ahead-of-print. https://doi.org/10.1108/IMR-02-2020-0028

This Article is brought to you for free and open access by the Graduate Business School at ARROW@TU Dublin. It has been accepted for inclusion in Articles by an authorized administrator of ARROW@TU Dublin. For more information, please contact arrow.admin@tudublin.ie, aisling.coyne@tudublin.ie,gerard.connolly@tudublin.ie.

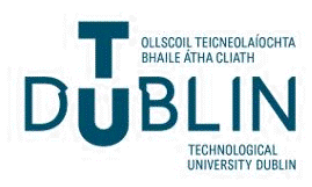


INTERNATIONAL ENTREPRENEURSHIP FROM EMERGING TO DEVELOPED MARKETS: AN INSTITUTIONAL PERSPECTIVE

\begin{tabular}{|r|l|}
\hline Journal: & International Marketing Review \\
\hline Manuscript ID & IMR-02-2020-0028.R2 \\
\hline Manuscript Type: & Original Article \\
\hline Keywords: & $\begin{array}{l}\text { International entrepreneurship, Processes, Institutions, Emerging } \\
\text { markets, Developed markets }\end{array}$ \\
\hline
\end{tabular}

\section{SCHOLARONE ${ }^{m}$ \\ Manuscripts}




\section{INTERNATIONAL ENTREPRENEURSHIP FROM EMERGING TO DEVELOPED MARKETS: AN INSTITIUTIONAL PERSPECTIVE}

\section{INTRODUCTION}

International entrepreneurship (IE) is defined as 'the cognitive and behavioural processes associated with the creation and exchange of value through the identification and exploitation of opportunities that cross national borders' (Peiris et al. 2012). The number of small and medium sized enterprises (SMEs) expanding from emerging to developed markets is growing (Gaur et al. 2014; Kujala and Tornross, 2018). Developed markets are attractive to emerging market (EM) entrepreneurs because they represent significant opportunities for growth (Bortoluzzi et al. 2018; Adomako et al., 2020; Yang and Wang, 2020), offer the potential to escape strong foreign competition domestically (Zhu et al. 2006, Fabian et al. 2009, Ahmad 2013) and the potential to escape dysfunctional home institutions (Wright et al. 2005, Yamakawa et al. 2008, Li and Deng 2017; Adomako et al., 2020; Wu and Deng, 2020).

This study investigates the institutional conditions shaping the IE process from emerging to developed markets. Institutions significantly shape entrepreneurial behaviour and strategy of internationalising EM firms (Wright et al. 2005; Deng and Zhang, 2018; $\mathrm{Wu}$ and Deng, 2020; Adomako et al., 2020). Although the institutional perspective is established as an approach to EM IE (e.g. Ahmed and Brennan, 2019; Vorley and Williams, 2016), very little consideration is given to the dual institutional environments that EM entrepreneurs are navigating as they venture internationally. These are the home and host country institutions where activities are enacted. They may be national, regional or local institutions (see for example Lang, Fink and Kibler, 2014; Zhang, Gao and Cho, 2017; Sadeghia, Nkongolo-Bakendab, Anderson and Dana, 2019). Indeed, since IE research has demonstrated that entrepreneurial actions are embedded in the socio-political environment where they take place (Bowen and DeClercq, 2008, Busenitz et al., 2000, Casper and Whitley, 2004, Jones et al., 2011, Spicer et al., 2000), where activities are across two domains of home and host countries, then understanding those institutional influences shaping IE across dual domains must be critical to explaining how the process evolves. With few exceptions (e.g. Drakopoulou Dodd, Wilson, Bhaird and Bisignano, 
2018; Yamakawa et al., 2008) very few studies adopt a dual institutional perspective to problems of IE. Moreover, we do not understand how home and host country institutions shape the IE stages as opportunities progress. By exploring the influence of home and host market institutions on IE activities across the stages from opportunity recognition to opportunity exploitation, we can make important contributions to IE, and in particular emerging to developed market IE where the chasm between institutional environments presents much greater challenges.

Institutions are defined as the rules of the game or humanly devised constraints that shape human interaction (North, 1990: 3). These are derived from formal rules such as regulatory structures, governmental agencies, laws, courts, professions, and informal rules such as societal and cultural practices that exert compliance pressures (DiMaggio \& Powell, 1991; Bruton et al., 2010). Institutions are considered central to the process of international entrepreneurship (North 1990, Yamakawa et al. 2008, Bruton et al. 2009, Ahmed and Brennan 2019, Torkkeli et al. 2019). Thus, how EM entrepreneurs identify international opportunities, how they mobilize resources, and commercialise ideas will involve formal and informal institutions (Bruton et al., 2009; Dana and Ratten, 2017).

Most institutional research on EMs to date has focused on the relationship between institutions and small firm domestic growth (Peng, 1997; Peng and Heath, 1996; Williams and Vorley, 2015; Dileo and Pereiro, 2019), EM SME internationalisation such as the drivers and rationales for internationalisation (Yamakawa et al., 2008; Ketkar and Acs, 2013), the extent and speed of internationalization (Lamotte and Colovic, 2015; Muralidharan and Pathak, 2017; Yang and Wang, 2020); and resources (Zhu et al., 2006). Despite repeated calls for more research on EM IE (Kiss et al., 2012; Smallbone et al. 2014, Meyer and Peng 2016, Paul and Benito 2018, Radulovich et al. 2018), research examining the EM IE process through an opportunity based approach remains relatively small (Volchek et al. 2013; Zaefarian et al., 2016; Dana and Ratten, 2017; Miocevic et al., 2018). Most studies remain conceptual, for example Li (2013) conceptually examined the link between home formal institutional transition and EM IE. Dana and Ratten's (2017) conceptual study focused on home market cultural influences on EM entrepreneurs' opportunity identification. What we do not understand is the evolving process, how opportunities progress and the influences of both home and host market institutional environments on shaping activities across those stages. Such studies are 
needed because EM entrepreneurs are expanding in foreign markets, including expansion into developed markets through an institutionally driven entrepreneurial process (Ibeh et al., 2012).

Managerial and policy contributions can be enhanced through this holistic approach, in particular as we adopt an activity perspective to defining stages in the IE process. Although underrepresented in research, calls to explore the activity level are required to bring theory closer to practice (Vahlne and Johanson, 2020; Contractor, Foss, Kundu and Lahiri, 2019). Furthermore, we argue that our holistic approach across IE stages connects a growing body of fragmented work from scholars within the EM IE field, creating a fruitful agenda for future research. Our emphasis on African entrepreneurship (i.e. Nigeria) feeds into a particularly neglected region of study that now demonstrates success in emerging to developed market IE.

An important argument of our study relates to the thesis of "institutional escapism" (Witt and Lewin, 2007; Mingo et al. 2018). The central thrust of institutional escapism is that firms are motivated to enter overseas markets to escape from home market institutional barriers and to survive and grow (Witt and Lewin, 2007; Yakakawa et al. 2008). In the context of EM entrepreneurs, inefficient institutions such as weak property rights, inadequate capital markets and weak government support may push entrepreneurs into foreign markets (Yamakawa et al. 2008; Adomako et al., 2020). However, the empirical literature validating institutional escapism outside of the multinational and state owned enterprise context is limited to a small number of studies (Deng and Zhang, 2018; Adomako et al., 2020; Wu and Deng, 2020). Despite the recent work supporting and developing the institutional escapism argument in the context of SME internationalization (Deng and Zhang, 2018; Adomako et al.,, 2020; Wu and Deng, 2020), these studies mostly take into account home market institutions and ignore the problem about whether SMEs or entrepreneurs actually do escape weak domestic institutions from internationalization. This is an important question of our study because through exploring the escapism thesis as IE progresses, we can shed some light on whether EM entrepreneurs actually escape home institutions, maybe developing the conversation from institutional escapism intent to escapism outcome.

Adopting a theoretical sampling approach we draw on a multiple case study methodology involving four information rich Nigerian cases active in the US. These four 
cases fulfilled our criteria for replication logic and independent exploration (Eisenhardt, 1989; Yin, 1994). We specifically explore how the home and host market institutional environment influences and shapes activities across the stages of IE.

Our findings make important contributions to the IE literature. First, our study contributes to the scant literature on EM IE (Yamakawa et al. 2008, 2013; Dana and Ratten, 2017; Jafari Sadeghi et al., 2019) by providing a more detailed and empirical insight into how institutions shape internationalization from emerging to developed markets. Those IE scholars examining the IE process from an institutional perspective have provided a partial address of the institutional-IE process relationship by restricting their analysis to specific aspects of the institutional environment and/or the IE process (e.g., García-Cabrera et al. 2016, Muralidharan and Pathak 2017; Yang et al., 2020). However, and answering specific calls for more empirical research on IE through institutional theory (Bruton et al., 2010; Muralidharan and Pathak, 2017), our study offers a more holistic analysis on the influence of home and host market institutions as the IE process evolves. Second, we provide a novel contribution to the home institutional escapism literature of interest to international business scholars (Witt and Lewin, 2007; Wu and Deng, 2020). Our study uniquely provides an understanding into the actualisation of EM escapism intent. Our contribution to institutional theory is through validation that formal and informal institutions constrain entrepreneurial action and by showing the influence of institutions on activities throughout the multi stage process in the context of of EM to developed market IE. Finally, by focusing on IE from Nigeria to the US we contribute to our understanding of how African firms expand into foreign markets (Ibeh et al., 2012; Liou and Nicholson, 2017; Hammerschlag et al., 2020). This is a neglected geographic context where few studies exist, yet the need for improved managerial and policy supports are high.

In the next section we present our theoretical framework to guide our empirical analysis. This is followed by our methodology then findings from our data analysis. We then discuss our findings in light of the contributions mentioned above, concluding with limitations and further research potential identified from our study. 


\section{THEORETICAL FRAMEWORK}

This section illustrates the theoretical assumptions guiding the investigation of how EM entrepreneurs' institutional environments shape the IE process into developed markets.

\section{An institutional-based view on international entrepreneurship}

Entrepreneurial actions are embedded within formal and informal institutions (Kuchař 2016), which enable and constrain the actions and interactions of economic agents (North 1990, Hitt et al. 2004, Veciana and Urbano 2008, Bruton et al. 2010, Ma et al. 2016, Ahmed and Brennan 2019, Torkkeli et al. 2019). Formal institutions refer to laws and regulation (North 1991). Formal rules are enacted, changed, and enforced by legislators, judges and bureaucrats, and other rule makers. Formal institutions require enforcement to ensure non-compliance is sanctioned (Voigt and Engerer 2002). Enforcement does not mean that sanctions are automatically imposed but rather there is a probability that violating an institutional rule will lead to sanctions. Countries typically differ in their level of "institutional enforceability". This is the extent to which formal institutions are efficiently and effectively protected by regulatory authorities, agencies through formal enforcement mechanisms (Williamson 1991, Johnson 2005). Informal institutions, on the other hand, are informal conventions, rules, norms and social routines (such as habitual forms of firm behaviour, consumption cultures, socialised work practices, transaction norms and so on). Specifically, Zenger et al. (2000) define informal institutions as "rules based on an implicit understanding being in most part, socially derived and therefore not accessible through written documents or necessary sanctioned through formal position"(p.6). Enforcement of informal institutions occurs through sanctions such as expulsions from community, ostracism by employees and communities or loss of reputation (Pejovich, 1999). Informal "rules of the game" include culture (Baker et al. 2005), networks/kinship ties (Peng 2004), and corruption.

\section{Institutions and emerging market international entrepreneurship}

There are various definitions of IE as the field has developed (see Oviatt and McDougall, 2005; Peiris et al. 2012; Zahra et al. 2014), but essentially it is identified through stages such as recognition, formation, evaluation, and exploitation of opportunities that may be 
cognitive or behavioural. International entrepreneurs identify, evaluate, develop and exploit opportunities through two major institutional domains: home market and host market. As such, we consider these two institutional jurisdictions (wherever possible) in our framework. We now conceptualize these stages of IE, and briefly consider how they are influenced by home and host market institutions.

Opportunity recognition relates to both the opportunity itself and opportunity-related processes that managers may become engaged in. Opportunity related processes revolve around managers' ability to recognize, discover, identify or create opportunities (Ensley et al. 2000, McCline et al. 2000, Shepherd and DeTienne 2001, Kolvereid and Isaksen 2006, Styles and Gray 2006, deTienne and chandler 2007). Recognition of an international opportunity in a developed market may be driven by the simultaneous influence of weak home market and strong developed market institutions (Peng 2003, Le et al. 2006, Witt and Lewin 2007, Puffer et al. 2010). EMs typically possess imperfect or inefficient institutions (North 1990, Khanna and Palepu 1997, Smallbone and Welter 2006, Williams and Vorley 2015) or commonly known as institutional voids (Khanna and Palepu, 1997). For EM entrepreneurs, weak home institutions increase investment risk, transaction costs and general uncertainty (North 1990, North 1994, Busenitz et al. 2000, Puffer et al. 2010, Peiris et al. 2012). This may incline EM entrepreneurs to enter developed markets to escape such constraining institutions (Bruton et al. 2010) and get "pulled inwards" by the relatively better-functioning legal institutions of developed economies (Yamakawa et al. 2008). In support, Coeurderoy and Murray (2008) examined the impact of the institutional environment on location choices and speed of internationalisation in British and German firms. They found that young entrepreneurial firms prefer to enter country markets that offered better regulatory protections for intellectual property. Adomako et al., (2020) found that EM firms operating in environments characterised by institutional voids are likely to become more interested in the international business environment which can trigger international venturing activities (p.10). These studies form the "escapism" thesis which argues EM firms are motivated to expand internationally to escape domestic institutional hardships (Bruton et al. 2010; Urbano and Alvarez 2014; Deng and Zhang, 2018; Wu and Deng, 2020). Less understood, however, is how and whether EM entrepreneurs do actually escape weak home formal institutions. 
Some EM entrepreneurs, however, intending to escape home institutional constraints may be unable to do so due to the lack of resources and confidence (Wu and Chen, 2014; Deng and Zhang, 2018). Other EM entrepreneurs initiating the escape intent may find how perceived challenging host market institutions work to undermine their ability to escape home institutions.

Opportunity development emphasizes the need for entrepreneurs to select and structure human, social/network, financial, and technological resources to assist commercialization and exploit opportunities (Ardichvili et al. 2003, Ireland et al. 2003, Cunneen et al. 2007, Oyson and Whittaker 2010). Building and accessing resource structures in unfamiliar environments may make it difficult for EM entrepreneurs to 'jump in' where new rules of the game exist and compete head to head against incumbent firms (McDougall, Shane and Oviatt 1994). Without adequate resources, EM entrepreneurs cannot compete against developed market firms which normally have richer resource portfolios (Hoskisson et al. 2004, Thomas et al. 2007). But informal institutions, such as through informal networks and cultural understanding can become valuable for EM entrepreneurs (Liou and Nicholson, 2017). In particular, existing or new informal networks may provide legitimacy with important host market institutions, and/or provide other resource support such as financial capital or knowledge to facilitate developed market entry (D'Angelo et al. 2013; Dana and Ratten, 2017; Oyedele and Firat, 2020). Yet kinship ties or other informal/personal network relationships may not provide meaningful support for some opportunity development activities in the developed market (Musteen et al., 2010; Williams and Vorley, 2016). Nevertheless, these relationships may still provide social capital that can help develop the entrepreneur as viable alliance or trading partners with developed market firms which can develop meaningful resources for the developed market (Hoskisson et al., 2013). However informal institutional differences such as different corporate values, national cultural norms and communication styles, can frustrate alliances between EM entrepreneurs and developed market firms (Owens et al, 2018; Golesorkhi et al. 2019).

Alternatively, EM entrepreneurs can leverage home government support agencies to provide information, and financial benefits such as tax incentives, tax deduction, and low interest loans (Hoskisson et al. 2013, Sharma et al. 2018). However, government support for entrepreneurs in emerging markets is often lacking (Hoskisson et al. 2013) and 
therefore, provide weak bases for nurturing the financial, organizational and technological resources that emerging market entrepreneurs require to compete (Hitt et al. 2000, London and Hart 2004, Wan 2005, Thomas et al. 2007, Lim et al. 2016). Taken together, weak formal home institutional support may decrease the EM entrepreneurs ability to cope with a divergent and challenging developed market institutional environment (Hitt et al. 2006). Thus, rather than escaping the home institutional context, EM entrepreneurs may become more dependent on home institutional support during the opportunity development phase. In addition to the interplay between formal home and host market institutions (Mingo et al, 2018), tensions and misalignment between home formal and informal institutions (Fuentelsaz et al. 2019) may further frustrate EM opportunity development in developed markets. Typical informal institutions within emerging markets, such as corruption, excessive business informality and contractual violation (North, 1990; Hoskisson et al. 2013; Wu and Deng, 2020) may lower the confidence and resource support among home government and financial organizations. EM entrepreneurs may moderate this institutional tension and gain home institutional trust through firm specific advantages (Curevo-Cazarrat \& Ramaurti, 2007) or the "halo effect" from presence or success in developing markets. Alternatively, EM entrepreneurs may have to avail of informal networks for resource support. Either way, the interactive effects of institutions between home and host markets should condition the EM entrepreneurs' efforts when gaining resources to exploit opportunities in developed markets.

Opportunity exploitation is the deployment of resources, actions, and investments to realize recognized opportunities (Knight 2001, Zahra et al. 2005, Foss and Klein 2012, Dunning 2013). Well established and efficient institutions within the developed market may facilitate exploitation of opportunities (Hitt et al. 2005, Wan 2005, Hitt et al. 2006; $\mathrm{Wu}$ et al., 2020). High quality institutions can make it easier for entrepreneurs to gain information on consumers, creditors and investors and managerial talent (Khanna et al. 2005). This institutional familiarity may reduce reliance on their weak home governments for support and assistance. On the other hand, EM entrepreneurs exploiting opportunities in developed economies with regulatory institutions of a different quality from those in the home institutional environment may experience additional costs and difficulties (Mingo et al, 2018). These costs and difficulties are, in part, due to the EM entrepreneurs 
limited knowledge $(\mathrm{Wu}, 2013)$ and less experience about operating in a different institutional system (Perkins, 2014).

Throughout opportunity exploitation, developed markets usually offer entrepreneurs high level of intellectual property right protection which lessens the risk of the expropriation of intellectual property and provides a more favorable institutional context for innovative activities (Wu et al., 2020). This could encourage EM entrepreneurs to invest resources in new technology and product development. Moreover, developed markets, such as the USA, have well-developed capital markets (advanced banking system, venture capitals, etc.) which can provide EM entrepreneurs with access to capital funding (Geleilate et al., 2016). Even so, institutional differences between emerging and developed economies may cause liability of foreignness (LOF) barriers for EM entrepreneurs (Kostova (1999, Joardar and $\mathrm{Wu}, 2017)$. LOF refers to a lack of credibility or discrimination from important market actors such as customers, financial institutions and suppliers (Hymer, 1976). EM entrepreneurs may often lack legitimacy among developed market institutional actors (Marano et al., 2017). Actors within host market institutions may use the EM entrepreneurs home country and institutional environment to assess the legitimacy and potential risk of the EM entrepreneur (Mingo et al. 2018). Legitimating actors within developed markets, such as customers, suppliers and partners, may develop unfavorable perceptions about EM entrepreneurs based on negative stereotypes about their countries of origin (Kostova \& Zaheer, 1999; Marano et al., 2017; Mihailova et al. 2019). Moreover, EM entrepreneurs with unreliable laws and regulations in their home country operate in an environment that fosters corruption and inefficiency which further lowers EM entrepreneurs' credibility and reputation (Yamakawa et al. 2008). Although these institutional tensions and differences between the home and host markets may constrain exploitation efforts, it may also encourage EM entrepreneurs to try harder to overcome such institutional barriers (Mihailova et al. 2019).

EM entrepreneurs may manage LOF through networks (Coviello and Munro 1997, Kostova and Zaheer 1999, Yeung 2002, Peng 2004, Langseth et al. 2016, Torkkeli et al. 2019). For example, EM entrepreneurs may also co-opt government bureaucrats to win state contracts or to secure government funding (Wan, 2005). Because of weak organizational and managerial resources of EM entrepreneurs, they may lack sufficient network capital to co-opt home government support to facilitate opportunity exploitation 
activities, or to avail of such support through the private sector. Whilst firms from developed economies may gain quality advice from various trade experts and consultancy firms (Gaur et al., 2001), EM government and private sector support can often be inadequate or non-existent due to home market institutional voids. Even so, EM entrepreneurs can learn to navigate around home market institutional voids (Adomako et al., 2020) and develop the capabilities to successfully exploit opportunities in developed markets (Luo and Tung, 2007; Geleilate et al., 2016).

In sum, the above clarifies the central focus of our research and outlines the conceptual foundations of our study. Although institutional and mainstream entrepreneurial research identifies, to some degree, that formal and informal institutions affects entrepreneurship, it has not been researched how home and host market institutions effect the process of international entrepreneurship for EM entrepreneurs. Throughout the process from opportunity recognition to development and then to exploitation, EM entrepreneurs are navigating and manoeuvring multiple institutional influences in two institutional settings. This study sets out to explore those dual settings shaping entrepreneurial activities from emerging to developed markets.

\section{METHODOLOGY}

There are mounting calls for more in-depth and qualitative understanding of the IE process from emerging markets to developed markets (Meyer and Peng, 2016; Kujala and Tornroos, 2018; Ji et al. 2019) and for more research to gain insights on institutional influences on the IE process (Bruton et al., 2010; Muralidharan and Pathak, 2017). In particular, we do not understand how home and host market institutions affect entrepreneurial opportunities as they progress between emerging markets and developed markets. As a result, we adopt a theory building and multiple case study design to generate new understanding of an underexplored research area (Eisenhardt 1989, Eisenhardt and Graebner 2007, Yin 1994). When exploring complex settings involving actual events and processes in practice, qualitative case research is both relevant and appropriate (Welch et al. 2016, Kujala and Törnroos 2018, Ji et al. 2019). Exploring and unearthing the complexities of entrepreneurial behavior in smaller firms points to a 
multiple case design to ensure an adequate number of temporal observations from which to build theory (Kuivalainen et al. 2012, Langley et al. 2013, Welch et al. 2016).

There are a number of reasons why Nigerian entrepreneurs are a good context for this study. Within the large global sphere of EMs significant differences and challenges for internationalisation exist. Nigeria is identified as a fast growth developing country categorized in the 'Next Eleven' as a potentially large economy of the future. Unlike many other developing nations, Nigeria's entrepreneurs have managed to successfully venture into developed markets, in particular the US (Dana and Ratten 2017, Kujala and Törnroos 2018). Consequently, a sample from which to explore this new phenomenon of EM to developed market IE exists among Nigerian firms. In addition, Nigeria is an important economy in the West Africa region identified by intergovernmental organizations as a priority development area (Ibeh et al. 2012, Amoako and Matlay 2015). These regions warrant particular attention to ensure appropriate policy and incentive targeting (Kujala and Törnroos 2018).

Starting our research and to assess the viability of the research setting we created a report on internationalising Nigerian SMEs. Most Nigerian entrepreneurs tend to expand their business into neighboring countries, but we identified that the US is also an important trading market. Nigeria is the second largest trading partner of the US in subSaharan Africa with US\$8.3 billion in total trade reported in 2019 (US Department of State).

To help develop the interview protocol and understand the logic of EM to developed market IE, we followed our initial report with four preliminary interviews with Nigerian entrepreneurs engaged in international business. These were interviewed in Autumn 2014 and came from textile, plastic export, film production and consulting backgrounds. These interviews identified themes such as escapism, social networks and financing issues in terms of important sets of activities of the IE process and the related institutional influences on those activities. Our high level prompt sheet is attached as Appendix A.

Particular successes promote the relevance of both the food industry and the film industry in the US market. The Nigerian film industry (Nollywood) is a US\$3.3 billion sector and the $2^{\text {nd }}$ largest film industry in the world. The importance of the food sector 
evolves from the large Nigerian population (estimated close to 400,000) in the US with high average household incomes. This ensures purchasing power and disposable income to spend on African themed products, especially food and entertainment. Cases were then selected from Nigeria's food and film industry because these sectors were able to successfully exploit opportunities (thus we could explore across all stages of IE). Furthermore, the two industries have 'polar type' characteristics allowing us to more easily observe contrasting patterns in the data creating more robust and deeply grounded theory (Eisenhardt, 1989; Eisenhardt and Graebner, 2007). Additionally, entrepreneurs willing to collaborate in this study and provide accessibility to interview participants and archival data sources were helpful in selecting the final cases (Pettigrew 1990, Hammersley and Atkinson 2007, Urbano, Toledano and Ribeiro-Soriano 2011).

Our sampling procedure responds to the need of grasping insights from paradigmatic cases (Hagen, Zucchella and Ghauri, 2019; Flyvbjerg, 2006), bearing in mind the newness of the phenomenon and relatively small number of successful SMEs. Our approach was inductive in nature rather than seeking generalizability through representativeness. Four cases met our strategy for theoretical sampling (Eisenhardt and Graebner, 2007): a co-owned and managed husband and wife team food processing firm in New Jersey (Case A); a film production company in New York owned by a male entrepreneur (Case B); a film production company in Austin, Texas owned by a female entrepreneur (Case C); and a food importing company in Houston, Texas co-owned and managed by a husband and wife team (Case D). These were all information rich cases that could be studied in depth (Patton, 1990; Perry, 1998). Each case could provide replication logic (Eisenhardt, 1989) whereby experiences could be treated as a set of independent experiments and then compared and contrasted across each case (Yin 1994).

Insert Table 1 about here .....

Table 1 outlines the characteristics of each case anonymized as Case A, Case B, Case C and Case D. Each of these cases successfully exploited opportunities in the US market. Two cases from the food sector and two from the film industry ensured more easy 
observation of patterns from polar type characteristics (Eisenhardt and Greabner 2007). In addition, we achieved other sampling objectives by variations in gender balance of the owner entrepreneurs, size variation, prior entrepreneurial experience and reasons for venturing overseas. Our preliminary interviews indicated that selecting a range of factors for early stage entrepreneurship would be preferable to explore the escapism thesis across the IE process from opportunity or necessity determinants recognised in early ventures (Angulo-Guerrero, Pérez-Moreno and Abad-Guerrero, 2017; Chen, Saarenketo and Puumalainen, 2018; Nikolaev, Boudreaux, and Palich. 2018).

Data was collected from semi structured interviews and observations with the entrepreneurs during an 11 month period from Summer 2015 to Spring 2016 (see Table 2). Interviews with entrepreneurs were corroborated by data collected from other stakeholders including other managers within the firm involved in the internationalisation process and external expert informants to sharpen construct definition and validity (Eisenhardt, 1989; Turcan, 2013). Overall, 4 interviews were collected from each case comprising 16 case interviews in total. Twelve additional external informant interviews were collected from institutional informants, academics and consultants which gave us the outsider perspective and reality check (Santos and Eisenhardt 2009). Combining entrepreneurial experiences with manager insights and expert informant perspectives helped us to learn as much as possible about the entrepreneur, the company and institutional influences before the interviews and also helped to corroborate the consistency of information reported by the entrepreneurs (Turcan, 2013). The twentyeight interviews in total yielded approximately 240 pages of interview data in the main data collection stage.

Interviews lasted between 50 minutes and two hours following the same high level protocol for all cases (see Appendix A). This was adapted as new aspects of interest were introduced into the research. All interviews were recorded and transcribed with field notes written up within 24 hours to reduce retrospective sense making that leads to bias (Turner and Rindova, 2012; Eisenhardt and Graebner, 2007).

Insert Table 2 about here 
As our data collection progressed, we began to analyse our cases. We conducted our data analysis in the iterative fashion appropriate to inductive research. Although presenting the analytical procedure sequentially as four major steps, in reality we conducted multiple iterations of analysis, constantly moving backwards and forwards between the data, emerging insights and the existing literature to interrogate meaning and eventually develop our findings (Locke 2000). Using nVivo to help with structure, coding and visualisation of our data, we adopted techniques for thematic analysis to provide a rich and detailed account of the patterns within the data (Braun and Clark, 2012).

Step 1. Examination of activities across IE. Drawing on various definitions of IE (Oviatt and McDougall, 2005; Peiris et al. 2012; Zahra et al. 2014) and insights from the different stages of the IE process identified in our literature review (e.g. Baron, 2006; He and Karami, 2016; Guo, Zhang and Gao, 2018), we identified the activities involved in the IE cycle. Taking this activity level micro focus provided an important scientific explanation of practice (Vahlne and Johanson, 2020; Contractor, Foss, Kundu and Lahiri, 2019) to delineate the stages of the IE process. Following the activity perspective we coded only specific actions or interactions of the actors rather than entrepreneurial intentions or beliefs (Jarzabkowski, 2005; Johnson, Melin, and Whittington, 2003). Using nVivo to generate first order concepts (empirical observations) and then aggregating similar and recurring codes thematically under broader categories (second order codes) we identified three sets of activities across three IE stages. These comprised Opportunity Recognition (scaling, seeking information, trial and error activities), Opportunity Development (setting up, resourcing activities) and Opportunity Exploration (production, shipment, marketing, sales activities).

Step 2. Exploring home and host country institutional influences across three opportunity stages. Our initial coding of the data pointed towards sets of activities that defined the stages of the IE process. The second step aimed to describe how formal and informal institutions shaped opportunities in these stages and potentially how they enabled or constrained their progress. We drew on the definition of North (1990) and others from our literature review to identify themes within the institutional rules and procedures (both formal and informal) that structure social interaction. From analysis of 
each case we made 485 empirical observations concerning institutional influences experienced. These included IP rights, censorship, the enforcement of contracts, social networks, financial constraints and access to finance and insurance, government supports and regulation, custom inspections and hiring of workers. Again, we aggregated these codes thematically assisted by nVivo.

Step 3. Cross case analysis. We then did a cross case pattern analysis to look beyond initial impressions and explore tensions and similarities between cases (Eisenhardt, 1989). Tables and graphs were used to present the data without destroying the meaning (Miles and Huberman, 1984). The between-case analyses revealed a few, rather predictable differences among the entrepreneurs, for example within different motivations for internationalization. Moreover, critical patterns concerning institutional impacts emerged, notably the evolution of escapism themes and the role of informal institutions across the stages.

Step 4. Theoretical underpinning. We next extracted theoretically explanatory dimensions from the first order findings. Opportunity Recognition, Opportunity Development and Opportunity Exploitation emerge as the activity stages of the IE process highlighted in Step 1. Concerning home and host country institutional influences across opportunities, these are categorised according to formal and informal influences as outlined in Table 3 and as explained more fully in our Findings section.

Insert Table 3 about here

As the constructs and relationships that emerged from the data were observed across multiple cases our theoretical framing is robust (Eisenhardt and Graebner, 2007; Turner and Rindova, 2012). Consistent with the methods of inductive inquiry, we checked the validity of our emerging insights with key informants by contacting entrepreneurs and requesting subsequent clarifications and elaboration of our ideas where necessary. Each case was developed from corroborating back and forth between the entrepreneurs, senior managers and external experts together with archival data. Our sampling strategy and data collection appropriate to understanding the complexities of 
institutional influences on entrepreneurial behaviour ensured that theoretical saturation emerged from our rich multi voice interrogation of the four cases and external informants.

\section{FINDINGS - INSTITUTIONS AND INTERNATIONAL ENTREPRENEURSHP}

\section{Opportunity recognition}

In this section, we show how formal and informal institutions influenced opportunity recognition in developed markets. The findings show the entrepreneurs intent to escape adverse home formal institutions. In addition, the findings show how informal institutions (social networks) facilitated the opportunity recognition decision. These are now explained.

\section{Intent to escape home formal institutions}

The findings reveal the entrepreneurs seeking to escape adverse home formal institutions and reduce their dependency on the domestic market by identifying an opportunity in the developed US market. For example, all cases explained the intent to escape weak institutional protection for IP rights which increased their costs and generally undermined local growth. The strengths of IP systems depend on two distinct elements of a country's institutional environment: the availability of IP protection and the effectiveness of public IP enforcement (Maskus 2002, Pajunen 2008, Peng et al. 2017). In terms of the first element, intellectual property law exists in Nigeria. The Nigerian Copyright Act 1999 (as amended) states that "no one shall make a copy of a film or distribute it for commercial purposes by way of rental, lease or hire without the permission of the IP owner." However, Nigeria's IP enforcement has not been effective for many years. The underfunded copyright commission agency (NCC), the slow judicial process, corruption, and high legal costs contributed to weak public enforcement. Unlike the US which has one of the most robust IP laws in the world with strict enforcement, the weak IP support in Nigeria provoked and encouraged major unauthorised copying and distribution of intellectual property. Around 90 percent of Nigeria's CDs, VCDs, and DVDs are pirated (due to organized crime). It is also estimated that for every legitimate copy, there are 
between 5 to 10 pirated copies on the market (Haynes, 2014). As a result, the entrepreneurs' sought to shift the focus from domestic operations towards international opportunities. Internationally, the Nigerian entrepreneurs were attracted by the higher levels of IP enforcement in the US market. The entrepreneurs expected the stable legal framework in the US with well-protected property rights would increase their confidence and prevent expropriation of their successful gains. In a similar way, Cases B and C, the film sector entrepreneurs', explained how local laws concerning domestic censorship laws underpinned, in part, the decision for US entry. Unlike US liberal censorship laws that merely require voluntary classification of motion pictures based on viewer age suitability, Nigerian censorship law is to all intents and purpose highly restrictive. In Nigeria, movie themes are strongly screened under a strong moral enforcement agenda of the Nigerian agency (NFVCB). This agency screens the stories, the picture contents, the target audience, and the distribution aspects. This strict censorship undermines the entrepreneurs' creative capabilities, as well as generally impeding local growth potential. In comparison, censorship regulations in the US, overseen by the Motion Picture Association of America (MPAA) were perceived a less restrictive institution of censorship laws in the US. The following quote provides supporting evidence:

\footnotetext{
"There are times the NFVCB would tell us to take out certain scenes, which they think those scenes are too bad for the audience. The problem with this thing they are doing is this. The creative person feels discouraged knowing that his idea is only inside his head, and he cannot see it come to reality. Of course, this is why we prefer the American market because, over there, we can express our creativity." [B-02]
}

Weak enforcement of contracts in Nigeria made entrepreneurship risky which contributed to low entrepreneurial prospects for domestic growth. Weak contract enforcement emboldened their business associates within the supply chain to breach business agreements for selfish gain. For example, as no written agreement was signed, Case C marketers started reproducing and distributing the firm's CDs illegally. The reduced home sales and, more critically, suppressed long-term confidence for domestic growth. 
This weak contractual law in Nigeria provided a strong impetus for the entrepreneurs to operate in a better functioning contractual environment. Indeed, the US institutional norms concerning legal contracting acted to support the entrepreneur's international ambitions and opportunity recognition. US commercial law is characterised by strict implementation and high levels of compliance with rigorous enforcement of contracts. For case $\mathrm{C}$, for example, these conditions encouraged an outward international focus and supported opportunity recognition in the US.

\section{Engaging informal host market institutions (social ties)}

The findings revealed the role of social and business ties in facilitating multiple activities within opportunity recognition such as scanning the environment, seeking new information and evaluation. First, the informal institution of ethnic ties between Nigeria and US contributed to the perceived US opportunity for Cases B and C (the exporting entrepreneurs). This opportunity revolved around the sizeable Africa diaspora in the US. An estimated 20 million Nigerians reside outside the country, with the majority living in the UK and the US. Both entrepreneurs perceived a niche market opportunity in the US through the export of Nigerian food products to the sizeable African diaspora across the US:

\footnotetext{
"We were surprised to find Nigerians in diaspora are looking forward to the food products that they are used to. They prefer to eat what they are already used to, but they are facing challenges in getting them. So when we approached them, we had a good reception by them saying "we have been looking for this" [A-01]
}

Interviewees also reported the positive use of informal networks to scan and evaluate the US opportunity. For example, Case A's informal analysis of the food market in Houston and Atlanta involved information from existing friends and family who lived in the US. On the other hand, Case $C$ visited several film studios in the US, registered with the Austin filmmakers' association and examined US trade magazines to become familiar with the local film scene. For example, the firm learned that the state of Austin in the US offered incentives to film sector firms such as direct loans and tax breaks to US incorporated film producers. All cases initiated "trial and error" phases to validate the identified opportunity. Again, the entrepreneurs' utilized social network ties to facilitate 
this process. For example, as Case A co-operated with friends within agri-food exporting to conduct shipment operations to the US as a test-run. In January 2007, the firm successfully shipped a cargo of processed yam tubers to Newark, which further validated the US opportunity. Other research links the identification and evaluation of international opportunities to networks (Sasi and Arenius 2008, Lorentz and Ghauri 2010, Kontinen and Ojala 2011, Mainela et al. 2014). In this research, networks provide valuable information for entrepreneurs' to become alert, and recognize new opportunities. Network members can educate entrepreneurs' about host market formal institutions or educating the entrepreneurs' about market/product gaps in the developed market (Johanson and Mattsson 2015).

\section{Institutions and international opportunity development}

In this section, we looked for insights into how institutions (both within home and host markets) influenced the EM entrepreneurs' selection and structuring of resources to facilitate the exploitation of opportunities. The evidence shows how the entrepreneurs struggled to escape home formal institutions while also experiencing positive and constraining host market formal institutions.

Constraints to escaping home formal institutions - adverse home financial institutions during financial resource mobilization

Adverse home market formal institutions restricted the entrepreneur's access to external financial resources towards the funding of the opportunity in the US. Indeed, the Nigerian entrepreneurs experienced a highly hostile financial environment in Nigeria. Loan application processes and eligibility criteria were overly demanding and exhausting. For example, interest rates were as high as $28 \%$ per annum and the firms also perceive collateral requirement for loans as highly unfavorable. Indeed, several Nigerian commercial banks demand that the value of the collateral must be three times the amount of credit requested:

"We went to the (Nigerian commercial) bank and showed them our plan. We want to expand our factory, buy more equipment and we needed working capital. But 
the bank came with ridiculous interest rates at 23\%, and they wanted collateral that is two times the value of the loan. In the end, we couldn't simply do it. So access to finance is difficult, and this does not allow room for international growth" [A-01]

The Nigerian banks were experiencing a considerable unstable banking environment and therefore dealing with low market capitalization. This, in turn, resulted in restricted corporate and SME lending. Second, and related, the insufficient commercial insurance market, and related risk management mechanisms, further exacerbated SME lending. Furthermore, Nigerian commercial banks demanded close examination of the SME's financial records. However, all cases possessed insufficient records of transactions or contracts signed with agents and distributors. The systemic culture of informal business practices in Nigeria bred non-compliance to company registration and formal record keeping. Consequently, the situation of incomplete business records discouraged banks and private investors from lending to entrepreneurs in the industry. Correspondingly, credit in the US appears much more accessible provided borrowers can present collateral and records of established transactions.

Constraints to escaping home formal institutions - poor government support Against these conditions, each case turned their attention to domestic government SME support. Case B approached a Nigerian development bank (government owned) which offered considerably lower interest rates (11\% IR) compared to the commercial banks (as noted above). Accepting their terms, Case B applied for a \$2M loan, tendering collateral, evidence of distribution arrangement and break down of costs - as required under credit policies of the bank. The Nigerian bank offered the SME a loan of the same value. Although the loan allowed the company to enter the US, it was not enough to finance the entire film production. Instead, the entrepreneur relied on additional funds from family members to complete production. Case A and D submitted applications to the Nigerian Export Import Bank (NEXIM). Again, the Nigerian Entrepreneurs' encountered barriers due to insufficient collateral and insufficient formal records. As with Case B, the Case A and $\mathrm{D}$ personal funds, and loans from friends were used to execute their project. Case A 
secured a bank loan facility of $\$ 500,000$. While this allowed the SME to procure equipment, hire and remunerate workers and agents, it was not enough to finance the entire export operation. However, Case D chose not to pursue government funding believing that the process was corrupted. As Case D commented:

"No development bank will give us money to help us grow our business either in Nigeria or in the US. They are busy helping themselves. You know, anything that has to do with government officials sitting together to approve something like loan simply connotes corruption. So we did not bother ourselves because we do not know anyone up there" [D-CEO].

Unlike the US context where access to government support is more streamlined and uncomplicated, Nigerian government incentive programs are largely ineffectual due to stringent criteria and corruption.

\section{Engaging host market regulation through social network knowledge}

Our analysis shows the formal US institutional environment to be both positive and negative for opportunity development. In this section, we show the positive role of formal host market institutions and social network knowledge for opportunity development. The entrepreneurs navigated the formal US regulation through relevant knowledge from family and friends. This relevant knowledge refers to information that offers immediate application to launching a venture in a given market environment (Kraemer and Venkataraman, 1997). Despite the perceived higher functioning of US regulation vis-àvis Nigerian institutions, and despite their prior experience of setting up firms, these entrepreneurs were uncertain of setting up a new organization in the US because they did not have the relevant knowledge of the new institutional environment. With Case $\mathrm{B}$, for example, the film entrepreneur used their attorney friend's expertise of US institutions and business environment to comply with US corporate registration law, and knowledge and contacts to secure an excellent office location in Broadway, New York. Furthermore, the entrepreneur used relevant knowledge of film sector friends in the US to recruit a 
high-quality artistic labor resource such as Hollywood star actors, film editors, and cinematographers. The positive role of informal networks to establish a US subsidiary is further evident with Case C. Through the advice of friends and colleagues in the US film sector, the firm established a US subsidiary in Austin Texas. Locating in Austin allowed the entrepreneur to take advantage of government incentives for small start-up film firms in that US state. In the next section, the findings show the negative role of host market formal institutions for opportunity development.

\section{Adverse host market financial institutions / country of origin discrimination}

The findings revealed an adverse reaction from the US finance community to the entrepreneurs which prevented access to much need financial resources. The pervasive dysfunctionality of home government support forced the Nigerian Entrepreneurs' to scope for US funding. Case A, for example, approached the US based export-import bank (EX-IM) for a financial loan. EX-IM were receptive towards lending exporters if they could show a distribution agreement with retailers or wholesalers. While the SME set up a potential buyer (US retailer), they could not meet the retailer's requirement to supply their 200 store network. Although the Nigerian Entrepreneurs' exercised considerable effort to access finance within the US, they failed due to stringent lending conditions in the US. For example, Case B submitted a loan application with the Bank of America for a \$2M loan to finance production of their film 'Holiday.' But management could not meet the bank's collateral terms. Moreover, financial and non-financial stakeholders discriminated against the entrepreneurs on the basis of ethnicity, or what the entrepreneurs' labelled, the "African factor." The following provides supporting evidence:

"There was a particular guy in New York (US); he was willing to cough out at least a million dollars for my movie, and we arranged a meeting. However, the moment he found out I was a Nigerian, he became uncomfortable. That just turned the table, and he made a U-turn, and he backed out." [C-CEO] 
"I will be honest with you; I tried to get a loan in the US. I tried, tried getting that. But they just shoved the whole thing under the table. It still boils down to that Nigerian factor. They don't trust us." [B-CEO]

Importantly, this hostile reaction of the US finance community cannot be isolated from the weak home institutions confronting the entrepreneurs. Considering the rampant IP violations and informal distribution in the Nigerian film industry, the US investors argued the film project could not be profitable in this context. As a result, they declined investment, which caused the entrepreneurs to focus on gaining support through home market financial institutions. In sum, the Nigerian entrepreneurs' struggled to gain host market institutional support for accessing finance arising from legitimacy concerns among developed market institutions. However, the lack of network capital within home and host market institutions contributed to such legitimacy problems.

\section{Engaging social ties and non-traditional financial sources}

The home and host formal institutional barriers to accessing financial resources for opportunity development resulted in the entrepreneurs resorting to other sources of finance. Similar to research within the entrepreneurship literature, institutional barriers experienced throughout opportunity development found our entrepreneurs working hard to gain the necessary financial resources to launch the US venture (Choi and Shepherd 2005; Haynie et al ., 2009). Specifically, the analysis showed how informal institutions (family and friend networks) further provided a financial life-line to those entrepreneurs' confronting serious financial difficulties. As a result of internationalising to the US, Case $\mathrm{A}$ and Case $\mathrm{C}$ were plunged into financial turmoil and turned to family/kinship ties. For example, Case A mobilized $\$ 300,000$ through friends and family funding as well as personal funds. This became the main development budget.

"We have been appealing to the bank for more funds, but so far, this has fallen on deaf ears. So, it is money borrowed from our family and friends that is supplementing our business efforts into the US." [A-CEO] 
Nigerian Entrepreneurs' employed other informal network resources for opportunity development. For example, the film producers substituted expensive shooting locations with physical spaces borrowed from friends and sought the support of local communities in Austin and New York, respectively. These communities volunteered personal spaces as locations, and some people posed as extras for free. Thus, SME informal networks mitigated, to a degree, the entrepreneurs resource and institutional barriers in international markets (Bruton et al. 2008, Li and Zhou 2010). Yet, as this informal network support did not entirely mitigate the institutional barriers, the entrepreneurs resorted to selffinancing and boot-strapping strategies. For example, and akin to financial bootstrapping (Zwane and Nyide, 2017; Miao et al., 2017), the entrepreneurs were forced to adapt and creatively use existing resources to reduce costs. Case $\mathrm{C}$ adopted cost-cutting measures (hiring lower cost third-rate actors known as ' $\mathrm{C}$ ' list, using less expensive equipment for production, and even changing the film script) which reduced overall production cost.

\section{Institutions and international opportunity exploitation}

In this section, we looked for insights into how institutions influenced the exploitation of the international opportunity in the developed market. Host and home markets institutions facilitated and constrained exploitation in the US.

\section{Adverse home government institutions and financial funding}

The cross-case findings, firstly, show how home government support enabled and constrained exploitation phase of the EM opportunity in developed markets. The Nigerian Entrepreneurs' entered the exploitation phase without adequate financial resources. Yet the Entrepreneurs" financial liabilities, not entirely resolved through resource development efforts, (see section above) caused sustained dependency on private and public sector financial institutions for exploitation activities. For example, Nigerian development bank funding required the applicant to sign an advance distribution deal with a marketing firm. In response, Case B launched aggressive marketing to secure a good marketing deal with a US partner. This secured a development bank loan to finance their US distribution. The following quote provides evidence: 
"I found out that you need to have an international distribution agreement signed to qualify for the (development) bank loan. Because of that, we started marketing the film to potential distributors in the US, even before the film production commenced." [B-CEO]

Similarly, Case C reported expending considerable time to meet the eligibility requirements for the government grant funding "Project Nollywood Act fund." The SME required capital to advance film production and distribution. However, their request for this government funding was unsuccessful due to stringent and cumbersome eligibility criteria. In the words of the entrepreneur:

\begin{abstract}
"I tried to get a government grant for our operations in the US, but what they asked from me was too much. They asked me to get contracts from these TV channels that they are willing to show my films and I should indicate to them the amount of money in the deal. I tried to explain to them that marketers will not sign a deal unless they see the finished product, but nobody listened." [C-CEO]
\end{abstract}

In contrast, Case B gained a government grant to finance US marketing and distribution. This, however, was helped through the firm's contacts within government. On the other hand, Case A, without network support, secured a commitment of government funding, albeit from the Export Expansion Grant (EEG) scheme. Yet the firm waited three years before receiving the funds.

Adverse home government regulatory conditions for marketing and distribution activities.

The exporting cases A and D complained how adverse formal home regulation and related procedures negatively impacted the entrepreneurs' exploitation activities. As part of the Nigerian Pre-shipment Inspection of Exports Act 1966, exporters are subject to a preshipment inspection which is excessively complicated, bureaucratic and inefficient. As 
a result, the Cases $\mathrm{A}$ and $\mathrm{D}$, complained of regular port delays which increased costs and sometimes contract defaulting. Additionally, the shipment of goods was sometimes compromised as a result of the Nigerian food regulation agency. Food exporters must comply with the Nigerian food regulatory agency [NAFDAC] for regulatory approval to produce and distribute products. Case A, for example, applied for permission to commence their processing of yam powder found how the food regulators were slow to finalize approval. This resulted in delayed shipment schedules and lost customer orders.

"In Nigeria, we pass through really cumbersome processes before our goods are allowed to sail from the ports. We cannot apply for inspections and get the certificate of inspection promptly. We are made to pay demurrage and sometimes there is even spoilage of the goods due to this delay. So all of this negatively impacted our US business" [D-CEO]

In sum, the analysis shows the adverse impact of home market formal institutions on exploitation activities. However, the findings in the next section further show how exploitation activities were positively enabled by host market regulation and government support.

Positive host market entry regulatory procedures, host government grant support and post-entry regulation

The findings reveal the enabling role of host market regulation and home government grant for the Nigerian entrepreneurs' exploitation of opportunities in developed markets. The exporting entrepreneurs reported efficient US customs procedures which expedited the shipment of goods and enhanced the overall sales/distribution process. US government grant assistance further benefited exploitation. Case A and D reflected on the Africa Growth Opportunity Act (AGOA), a preferential trade arrangement that offered incentives for exporters within African countries to export their products to US duty-free. Case D avoided AGOA as they viewed the procedures lengthy and cumbersome. Case A, however, applied and satisfied the eligibility conditions of AGOA and therefore exported 
their goods into the US without a tariff charge. This enhanced cost competitiveness. The following quote provide evidence:

"The AGOA programme really helped us in America in the sense of being more competitive. We do not pay duty because we are dealing with food. Food is under AGOA where duties are not paid. Because of that, we can afford to bring our price lower in the US, which makes us more competitive" [A-01].

US contract regulation further benefited the entrepreneurs' exploitation processes of market entry, labour management and networking. Each case conformed to host market institutional rules on foreign company registration, contracts, hiring workers, custom inspections enhance their commercialization in the US. These productive formal institutions supported IE through legitimacy, reducing uncertainties and enabling market support (DiMaggio and Powell 1983, Webb et al. 2010). Against the stronger legal environment in the US, Case B confidently formed contractual partnerships to distribute four film productions in the US. Such relationships provided the SME increased creditability/legitimacy in the US. However, other legitimacy building strategies were evident. For example, Cases B, to manage ethnicity discrimination in the US, altered production content, produced an occasional film suitable for US viewers, providing educating seminars to shift negative perceptions, and selecting US actors receptive to African culture. Case D initiated organizational learning to satisfy quality standards of the US regulatory agency (FDA). The learning of new food production techniques, packaging, and labeling which secured FDA approved production in the US. Taken together, the findings show EM Entrepreneurs' attempting to overcome formal institutional constraints in the developed market through several pro-active legitimization building strategies.

\section{DISCUSSION AND CONCLUSION}

In this study, we sought to examine how institutions influence EM IE into developed markets. We found that the EM entrepreneurs' recognition, development, and 
exploitation of international opportunities in a developed market is strongly conditioned through both home and host market institutions.

Our findings contribute to the IE literature in several ways. First, our study extends the scant research on the opportunity-based process of international entrepreneurship (IE) in the context of emerging market (EM) entrepreneurs (Volchek et al. 2013; Zaefarian et al., 2016; Dimitratos et al. 2016; Dana and Ratten, 2017; Miocevic et al., 2018; Jafari Sadeghi et al., 2019). Answering several calls for more research on EM IE (Kiss et al., 2012; Smallbone et al., 2014), the findings show how EM IE activities are institutionally embedded within both the formal and informal home and host markets. When expanding into the US market, the Nigeran entrepreneurs found themselves handling multiple institutional systems from creating and recognising opportunities, right through to the commercialization phase of the business operation. From the start of the process, entrepreneurial activities were strongly affected by host and home market institutions. While mostly conceptual studies show how home institutions shape EM IE in the formative stages of the IE process (Li, 2013; Dana and Ratten, 2017), our empirical study moves beyond this research when capturing how home and host formal and informal institutions are conditioning the entire IE process. This is an important contribution to EM IE academic research and managerial practice because despite the rich tradition on research in emerging economies, there are few efforts to explain how institutions influence IE activities and how EM entrepreneurs cope with their challenging institutional environment throughout the process. To the best of our knowledge, this is the first empirical study to understand across the stages of IE how home and host market institutional contexts shape the activities of EM entrepreneurs.

Focusing on the entire process of IE through an institutional perspective further addresses an omission in the wider IE literature (Bruton et al., 2010). The study of IE activities from an institutional perspective has been limited and largely conceptual (Bruton et al, 2010; Szyliowicz and Galvin, 2010). Although a small number of empirical studies have explored the effects of institutions on the opportunity recognition stage of the IE process (Muralidharn and Patak, 2017; Lundberg and Rehnfors, 2018), our study captures the effects of home and host institutions on multiple stages of the IE process. At the same time, our study theoretically contributes to new institutional economics by 
validating how formal and informal institutions constrain entrepreneurial action. Yet we further add to institutional theory by showing how institutions shape IE actions and outcomes throughout the holistic, multi stage IE process. Moreover, our research captures the importance of incorporating both home and market institutional contexts when applying institutional theory to understand IE. We found how the salience of host market institutional effects could not be neatly divorced from home market institution, and vice versa. While requiring further research, this responds to recent calls for better understanding into the interactions between formal and informal institutions between home and host markets on entrepreneurial entry and international entrepreneurship behaviour (e.g. Mingo et al. 2018; Bordreaux, Nikoleav and Klein, 2019; Torkkeli, Kuivalainen, Saarenketo and Puumalainen, 2019).

Thirdly, our findings reveal how the entrepreneurs' home market and host market institutional environment simultaneously enhanced international opportunity recognition in the developed market. It is important to stress the institutional environment includes both formal and informal institutions. The Nigerian entrepreneurs were pushed into the US to escape multiple dysfunctional formal home institutions. As Batjargal et al. (2013: 1031) aptly state, the confluence of weak and inefficient institutions often creates a hostile context for entrepreneurs due to negative synergy among the various institutions. This finding supports the IB institutonal escapsim view (Witt and Lewin, 2007; CuervoCazurra and Ramamunti, 2017) and adds to recent studies finding support for weak home institutons as antecedents of EM SME internationalization (Adomako et al., 2020; Wu and Deng, 2020). However, adding to this research, we found how quality host market regulation and host market based informal network support further impacted the decision to internationalize. The use of ethnic based ties in the host market alerted the entrepreneurs to host market institutional quality, as well as enhancing their familiarity of the new market. This simultaneous influence of home and host institutions behind the entrepreneurial internationalization decision supports Mingo et al., (2018) finding that the effects of home country institutions on internationalization cannot be isolated from the effects of host country.

Fourth, adding to research on EM IE (Gonzalez-Perez et al. 2016; Dana and Ratten 2017), our study provides insights into how institutions (both within home and 
host markets) enabled and constrained EM opportunity development in the developed market. As expected, adverse or low-quality formal home institutions (weak government financing schemes and private sector financial institutions) contrained financial mobilization efforts and forced the EM enterpreneurs to seek financial reosurces within the host market. Yet the EM entrepreneurs lack of reputation and legitmacy with US financial providers curtailed such resource access efforts (Kostova and Zaheer, 1999). However, our study shows the informal institutions (or lack of) explain the institutonal resistance in both home and host markets. Prevailing informal business norms within Nigeria (unregistered businesses and poor business transaction recording), prevented compliance with the fianancial sector's formal lending requirements. Within the host market, ethnic discriminaton and poor trust in the Nigerian business environment, arising from perceptions of excessive business informality within Nigeria, caused resitance to the entrepreneurs. The entrepreneurs lack of business and government network captial within the home and host markets excaberated these institutonal barriers (Deng and Zeng, 2018). Although obviously requiring more detailed research, this inherent misalignment between formal and informal institutions within the host market, and across host and home markets, adversely impacted EM opportunity development, and again, illustrates the interplay of host and home market institutions (Mingo et al., 2018). It further suggests future researchers should pay more attention to how informal institutions enable and constrain small firm internationalization.

Fifth, our study closes the cycle with opportunity exploitation. Although a few studies have discussed opportunity exploitation in IE (Vasilchenko and Morrish, 2011; Lindstrand and Hanell, 2017; Miocevic and Morgan, 2018), this stream generally avoids situating the IE exploitation in a institutional context. Adding to this literature, our findings show home market institutions imposing an adverse impact on exploitation activities, whilst efficient host market institutons enhanced opportunity exploitation. Moreover, we show how EM entrepreneurs seek to pro-actively legitimise their business during the exploitation phase in developed markets (Oliver 1991; Bangara et al 2012). For example, in response to the tendancy in the US towards consumer ethnocentrism (Shimp and Sharma 1987), entrepreneurs from the film sector cases managed this cultural bias by adjusting content of the product or service, or providing knowledge and awareness 
through education seminars. Essentially, we show how insitutitonal interactions are gradually transferring from the home market to the host market in the IE process.

In addition to the previously identified contributions to IE research, our findings linking institutons to the IE phases of opportunity development and exploitation allows a contribution to the SME internationalization studies investigating the institutional escapism view in several ways (Witt and Lewin, 2007; Wu and Deng, 2020). As this work concentrated on the initial investment decision, they avoid ascertaining if such institutional escapism becomes a reality. Thus, as a novel contribution to the literature, we show EM entrepreneurs escaping some formal institutions through internationalization but struggling to escape other home formal institutions at latter stages of the process. This finding is an important contribution to both the IB and IE literatures and managerial practice because we suggest that IE internationalization may not guarantee home institutional escape but can rather increase dependency on certain home institutions. Our study strongly encourages future studies to build on this important finding with a more indepth examination of the actualization of EM entrepreneurial institutonal esapsim intent.

Sixth, our findings show how EM entrepreneurs leveraging informal institutional ties (family and social network ties) facilitate each stage of the IE process. This confirms other studies on the role of networks during international opportunity recognition (Sasi and Arenius 2008, Lorentz and Ghauri 2010, Kontinen and Ojala 2011, Vasilchenko and Morrish, 2011; Zaefarian et al., 2016; Masiello and Izzo, 2019). However, this prior research mostly ignores considering the role of social networks in the other stages of the IE process. Adding to the IE literature, the case studies show the entrepreneurs, throughout opportunity development, relying on social ties for important development activities. Despite the perceived higher functioning of US regulation vis-à-vis Nigerian institutions, and despite their prior experience of setting up firms, the EM entrepreneurs were uncertain of setting up a new organization in the US as lacking relevant knowledge of the new institutional environment. As institutional differences can interfere with the transfer of knowledge across countries (Kostova, 1999; Scott, 1995), the EM entrepreneurs acquired the relevant institutional knowledge through social ties to help them with registering their new subsidiaries, acquire sites, recruiting employees, as well 
as providing financial support. Using social network ties for the development phase supports Lindstrand and Hanell's (2017: 660) argument that the firm's current network relationships in the host country and knowledge acquired in interaction with these relationships plays a critical role in opportunity development and exploitation. These findings also add to IE research by enhancing our understanding of how informal institutions shape the IE process (see Muralidharan and Pathak, 2017). This is an important addition to the IE literature because little effort has been devoted to understanding how informal institutions influence IE. Although Muralidharm and Patak (2017) identified how certain home informal institutions motivate the international entrepreneurs' decision to expand abroad, we show the positive and constraining roles of informal institutions to identify, develop and exploit international opportunities.

Importantly, the findings however, identify limits to the use of social networks in the development and exploitation phases of IE. Social networks could not aid the entrepreneurs with legitimacy problems and may have underestimated the challenges facing the entrepreneurs when pursuing private sector financing. This remains consistent with Musteen et al's., (2010) argument that the social network enhancing firms to pursue international opportunities soon do not necessarily help them in the exploitation of such opportunities (p.203). In response, the EM entrepreneurs had to employ their individual resources of personal finance and financial boot-strapping. This failure of entrepreneurs to acquire traditional financing during the venture-creation process often leads to entrepreneurs employing non-traditional financing such as self-financing and bootstrapping (Alvarez et al ., 2013; Foss et al ., 2008). Bootstrapping allowed the EM entrepreneurs to cope with their lack of legitimacy in the host market (Grichnik et al., 2014; Brinckmann et., 2019) as well coping with serious home market institutional voids. Interestingly, this individual resourcefulness and related high commitment enabled these EM entrepreneurs to both survive and sustain developed market operations. Although not coming through in this research, we suspect powerful informal institutions may be underpinning this personal commitment to internationalization (Muralidharn and Patak, 2017), and therefore, encourage future studies to examine the links between individual resourcefulness and informal institutions within IE. 
Finally, our study answers the call for more studies on EM to developed market entrepreneurship (Wright et al., 2005; Yamakawa et al., 2008). While previous studies have focused on firm internationalization into developed markets (Yamakawa, 2008; Kujala and Tornross, 2018), our study explored the entrepreneurial perspective. Moreover, by focusing on IE from Nigeria to the US we contribute to our understanding of how African firms expand into foreign markets (Ibeh et al., 2012; Liou and Nicholson, 2017; Hammerschlag et al., 2020). This answers several calls for more research on African firm internationalization (Ibeh et al., 2014; Obeng et al., 2014; Awankwah et al, 2018).

\section{Managerial and policy implications}

The findings of the study suggest EM entrepreneurs should be careful reacting to constraining domestic environments through entrepreneurial internationalization into developed markets. Developed markets pose enormous risks for EM entrepreneurs possessing insufficient home and host market institutional support and without adequate resources. In particular, EM entrepreneurs can experience country of origin discrimination when engaging with institutional stakeholders in the opportunity development stage. Our findings suggest that EM entrepreneurs, plagued by weak institutions and poor resources, should, in the first instance, seek to build capacity and resources before initiating developed market expansion. EM entrepreneurs seeking to capitalise on an international opportunity without sufficient institutional support and internal resources is highly opportunistic. Our findings, on the other hand, suggest a strategic and cautious approach to EM entrepreneurship in developed markets. EM entrepreneurs' strategic approach could involve learning to manage home institutional constraints such as developing networks to leverage government financing, and pursuing diversification into geographically and institutionally closer emerging markets. These strategic actions may yield the capital, networks and experience for successful future developed market operations. Moreover, gaining legitimacy among developed market institutional actors, including reducing the potential for discriminatory practices, may require engaging in status building activities such as entering for industry awards or building intermediary connections. Furthermore, our findings caution against over- 
relying on informal networks to support opportunity recognition, development and exploitation activities. While social networks should not be dismissed in recognising and evaluating opportunities, using formalized planning will yield higher quality information to validate the perceived opportunity and identify potential institutional and market risks. Finally, the strategy of creating formal business relationships for the development and exploitation phases seems logical for this strategic approach to EM entrepreneurship in developed markets.

In addition, this paper provides policy implications. In view of the adverse impact of Nigerians institutional framework on the international expansion of Nigerian SMEs, this paper recommends several realistic design and implementation improvements to enhance support for Nigerian entrepreneurs. First, we advise the need for greater support, transparency and fairness in the government incentive scheme application process. We suggest a dedicated 'know your eligibility' helpdesk be established at those government institutions administering incentive schemes. Second, in order to avoid regulatory bottlenecks for exporters relating to seeking permits and inspections, the operational guidelines of relevant regulatory agencies should be revised to incorporate specific timelines within which particular services must be rendered to a client. For example, the new guideline should mandate the Nigerian pre-shipment inspection agency to carry out inspections and provide certificates of clearance within twenty-four hours, provided the exporter has completed the correct documents and paid the required fees. For US policy makers, good quality training among staff to unconscious bias and developing good working relationships with ethnically based business representative bodies can create awareness of the potential for discrimination and ensure that distribution channels for information and feedback are appropriate.

\section{Limitations and directions for future research}

A number of limitations of our study can be identified which provide several fruitful avenues for future scholarship. In our discussion we identify aspects for future research possibilities concerning escapism outcomes, informal institutional influence on personal commitments to internationalise, and misalignment of formal and informal institutions 
between home and host markets. Other interesting directions for future research are detailed here.

First, the study was based on four Nigerian cases entering the US, and the findings may not be generalised to other emerging and developed markets. Replicating our research design across other emerging and developed countries should build our understanding and contribute to both IE and IB literatures. Related, the generalisability of our study is further constrained by our focus on just two industries with polar characteristics (food and film). Future related studies could seek to obtain data within other manufacturing and service sectors.

Second, our examination of the institutional context in emerging market IE does not delineate the categories of institutions, rather we identify them only as home or host market. Future studies should identify influences from institutional categories such as national, regional, local or supranational institutions across the stages of IE.

Third, our study stands apart from other IE-institutional studies in that we have situated the entire IE process (opportunity recognition, development and exploitation) within the EM entrepreneurs' home and host institutional environment. However, this wide scope of investigation prevented a more nuanced picture emerging on the institutional conditions within each phase of IE. More in-depth insights can be achieved when future studies investigate the links between specific institutional domains (host, home, formal or informal) and specific IE phases or activities. For example, whilst we have added to the knowledge on the role of informal institutions within IE (Muralidharan and Pathak, 2017), we would invite future studies to examine this particular aspect of the IE-institutional relationship.

Finally, although our study finds significant links between institutions and the IE process, it is logical to suspect that personal conditions and characteristics are possibly interacting with the IE and institutional relationship. For example, Yang et al., (2020) found how personality and motivational antecedents interact with home country institutional conditions in determining early stage entrepreneurial internationalization. Thus, the IE literature will be advanced if future studies examine the influences of individual and institutional conditions within IE. 


\section{REFERENCES}

Ahmad, S. Z. (2013). "Slow growth or rapid internationalization in emerging markets: The case of Maybank Berhad." Global Business and Organizational Excellence 33(1): 19-39.

Ahmed, F. U. and L. Brennan (2019). "An institution-based view of firms' early internationalization: Effectiveness of national export promotion policies." International Marketing Review.

Adomako, S., J. Amankwah-Amoah, G. O. Dankwah, A. Danso and F. Donbesuur (2019). "Institutional voids, international learning effort and internationalization of emerging market new ventures." Journal of International Management 25(4): 100666.

Alvarez, S. A., Barney, J. B., \& Anderson, P. (2013). Forming and exploiting opportunities: The implications of discovery and creation processes for entrepreneurial and organizational research. Organization Science, 24(1): 301-317.

Amoako, I. O. and H. Matlay (2015). "Norms and trust-shaping relationships among food-exporting SMEs in Ghana." The International Journal of Entrepreneurship and Innovation 16(2): 123-134.

Ahsan, M., Adomako, S., \& Mole, K. F. (2020). Perceived institutional support and small venture performance: The mediating role of entrepreneurial persistence. International Small Business Journal, , 26624262094319.

Angulo-Guerrero, M. J., S. Pérez-Moreno and I. M. Abad-Guerrero (2017). "How economic freedom affects opportunity and necessity entrepreneurship in the OECD countries." Journal of Business Research 73: 30-37.

Ardichvili, A., R. Cardozo and S. Ray (2003). "A theory of entrepreneurial opportunity identification and development." Journal of Business venturing 18(1): 105-123.

Baker, T., E. Gedajlovic and M. Lubatkin (2005). "A framework for comparing entrepreneurship processes across nations." Journal of International Business Studies 36(5): 492-504.

Bangara, A., S. Freeman and W. Schroder (2012). "Legitimacy and accelerated internationalisation: An Indian perspective." Journal of World Business 47(4): 623634.

Baron, R. A. (2006). Opportunity recognition as pattern recognition: How entrepreneurs "Connect the dots" to identify new business opportunities. Academy of Management Perspectives, 20(1): 104-119.

Batjargal, B., M. A. Hitt, A. S. Tsui, J.-L. Arregle, J. W. Webb and T. L. Miller (2013). "Institutional polycentrism, entrepreneurs' social networks, and new venture growth." Academy of Management Journal 56(4): 1024-1049. 
Boudreaux, C. J., Nikolaev, B. N., \& Klein, P. (2019). Socio-cognitive traits and entrepreneurship: The moderating role of economic institutions. Journal of Business Venturing, 34(1): 178-196.

Bortoluzzi, G., S. Kadic-Maglajlic, M. Arslanagic-Kalajdzic and B. Balboni (2018). "Innovativeness as a driver of the international expansion of developing markets' firms: evidence of curvilinear effects." International Marketing Review 35(2): 215235.

Brinckmann, J., Villanueva, J., Grichnik, D., \& Singh, L. (2019). Sources of strategic flexibility in new ventures: An analysis of the role of resource leveraging practices. Strategic Entrepreneurship Journal, 13(2): 154-178.

Bruton, G. D., D. Ahlstrom and H. L. Li (2010). "Institutional theory and entrepreneurship: where are we now and where do we need to move in the future?" Entrepreneurship theory and practice 34(3): 421-440.

Bruton, G. D., D. Ahlstrom and K. Obloj (2008). "Entrepreneurship in emerging economies: Where are we today and where should the research go in the future." Entrepreneurship theory and practice 32(1): 1-14.

Bruton, G. D., D. Ahlstrom and T. Puky (2009). "Institutional differences and the development of entrepreneurial ventures: A comparison of the venture capital industries in Latin America and Asia." Journal of International Business Studies 40(5): 762-778.

Busenitz, L. W., C. Gomez and J. W. Spencer (2000). "Country institutional profiles: Unlocking entrepreneurial phenomena." Academy of Management Journal 43(5): 994-1003.

Chana, Y., Styles, C., \& Wilkinson, I. (2009). The recognition of first time international entrepreneurial opportunities: Evidence from firms in knowledge-based industries. International Marketing Review, 26(1): 30-61.

Chen, J., Saarenketo, S., \& Puumalainen, K. (2018). Home country institutions, social value orientation, and the internationalization of ventures. International Business Review, 27(2): 443-454.

Braun, V., and V. Clarke. (2012). "Thematic Analysis." In APA Handbook of Research Methods in Psychology, edited by H. Cooper, Vol. 2: Research Designs, 57-71. Washington, DC: APA books.

Choi, Y. R. and D. A. Shepherd (2005). "Stakeholder perceptions of age and other dimensions of newness." Journal of management 31(4): 573-596.

Coeurderoy, R., \& Murray, G. (2008). Regulatory environments and the location decision: Evidence from the early foreign market entries of new-technology-based firms. Journal of International Business Studies, 39(4): 670-687.

Contractor, F., Foss, N. J., Kundu, S., \& Lahiri, S. (2019). Viewing global strategy through a microfoundations lens. Global Strategy Journal, 9(1): 3-18. 
Coviello, N. and H. Munro (1997). "Network relationships and the internationalisation process of small software firms." International business review 6(4): 361-386.

Coviello, N. E. and M. V. Jones (2004). "Methodological issues in international entrepreneurship research." Journal of Business Venturing 19(4): 485-508.

Cuervo-Cazurra, A. (2016). "Corruption in international business." Journal of World Business 51(1): 35-49.

Cuervo-Cazurra, A. and Ramamurti, R. (2017), "Home country underdevelopment and internationalization: Innovation-based and escape-based internationalization", Competitiveness Review, Vol. 27 No. 3, pp. 217-230.

Cunneen, D., G. J. Mankelow and B. Gibson (2007). "Towards a process model of independent growth firm creation." Small Enterprise Research 15(1): 90-105.

D'Angelo, A., A. Majocchi, A. Zucchella and T. Buck (2013). "Geographical pathways for SME internationalization: insights from an Italian sample." International Marketing Review 30(2): 80-105.

Dana, L.-P. and V. Ratten (2017). "International entrepreneurship in resource-rich landlocked African countries." Journal of International Entrepreneurship 15(4): 416-435.

Deng, P. and Zhang, S. (2018). Institutional quality and internationalization of emerging market firms: Focusing on Chinese SMEs. Journal of Business Research, 92, pp.279-289.

DeTienne, D. R. and G. N. Chandler (2007). "The role of gender in opportunity identification." Entrepreneurship theory and practice 31(3): 365-386.

Dileo, I. and T. G. Pereiro (2019). "Assessing the impact of individual and context factors on the entrepreneurial process. A cross-country multilevel approach." International Entrepreneurship and Management Journal 15(4): 1393-1441.

DiMaggio, P. and W. W. Powell (1983). "The iron cage revisited: Collective rationality and institutional isomorphism in organizational fields." American sociological review 48(2): 147-160.

Dimitratos, P., T. Buck, M. Fletcher and N. Li (2016). "The motivation of international entrepreneurship: The case of Chinese transnational entrepreneurs." International business review 25(5): 1103-1113.

Dimitratos, P., S. Lioukas and S. Carter (2004). "The relationship between entrepreneurship and international performance: the importance of domestic environment." International Business Review 13(1): 19-41.

Dunning, J. H. (2013). International production and the multinational enterprise (RLE international business), Routledge.

Eisenhardt, K. M. (1989). "Building theories from case study research." Academy of management review 14(4): 532-550.

Eisenhardt, K. M. and M. E. Graebner (2007). "Theory building from cases: Opportunities and challenges." Academy of Management Journal 50(1): 25-32. 
Ensley, M., J. Carland and J. Carland (2000). "Investigating the existence of the lead entrepreneur." Journal of Small Business Management 38: 59-77.

Fabian, F., H. Molina and G. Labianca (2009). "Understanding decisions to internationalize by small and medium-sized firms located in an emerging market." Management International Review 49(5): 537.

Flyvbjerg, B. (2006), "Five misunderstandings about case-study research", Qualitative Inquiry, Vol. 12 No. 2, pp. 219-245.

Foss, N. J. and P. G. Klein (2012). Organizing entrepreneurial judgment: A new approach to the firm, Cambridge University Press.

Foss, N. J., Klein, P. G., Kor, Y. Y., \& Mahoney, J. T. (2008). Entrepreneurship, subjectivism, and the resource-based view: Toward a new synthesis. Strategic Entrepreneurship Journal, 2(1), 73-94.

Fuentelsaz, L., C. González and J. P. Maicas (2019). "Formal institutions and opportunity entrepreneurship. The contingent role of informal institutions." BRQ Business Research Quarterly 22(1): 5-24.

García-Cabrera, A. M., García-Soto, M. G., \& Durán-Herrera, J. J. (2016). Opportunity motivation and SME internationalisation in emerging countries: Evidence from entrepreneurs' perception of institutions. International Entrepreneurship and Management Journal, 12(3), 879-910.

Gaur, A. S., V. Kumar and D. Singh (2014). "Institutions, resources, and internationalization of emerging economy firms." Journal of World Business 49(1): 12-20.

Geleilate, J. G., Magnusson, P., Parente, R. C., \& Alvarado-Vargas, M. J. (2016). Home country institutional effects on the Multinationality-Performance relationship: A comparison between emerging and developed market multinationals. Journal of International Management, 22(4), 380-402.

Glavas, C., S. Mathews and C. Bianchi (2017). "International opportunity recognition as a critical component for leveraging Internet capabilities and international market performance." Journal of international entrepreneurship 15(1): 1-35.

Gohmann, S. F. (2012). "Institutions, latent entrepreneurship, and self-employment: An international comparison." Entrepreneurship Theory and Practice 36(2): 295-321.

Golesorkhi, S., R. Mersland, T. Rand $\varnothing y$ and O. Shenkar (2019). "The performance impact of informal and formal institutional differences in cross-border alliances." International Business Review 28(1): 104-118.

Gómez-Haro, S., J. A. Aragón-Correa and E. Cordón-Pozo (2011). "Differentiating the effects of the institutional environment on corporate entrepreneurship." Management Decision 49(10): 1677-1693.

Granovetter, M. (2005). "The impact of social structure on economic outcomes." Journal of economic perspectives 19(1): 33-50. 
Grichnik, D., Brinckmann, J., Singh, L., \& Manigart, S. (2014). Beyond environmental scarcity: Human and social capital as driving forces of bootstrapping activities. Journal of Business Venturing, 29(2), 310-326.

Guo, Z., Zhang, J., \& Gao, L. (2018). It is not a panacea! the conditional effect of bricolage in SME opportunity exploitation. R \& D Management, 48(5), 603-614.

Hagen, B., A. Zucchella and P. N. Ghauri (2019). "From fragile to agile: marketing as a key driver of entrepreneurial internationalization." International Marketing Review. 36(2): 260-288.

Hammerschlag, Z., Bick, G., \& Luiz, J. M. (2020). The internationalization of african fintech firms: Marketing strategies for successful intra-africa expansion. International Marketing Review, 37(2), 299-317.

Hammersley, M. and P. Atkinson (2007). Ethnography: Principles in practice, Routledge.

Harris, S. G. and R. I. Sutton (1986). "Functions of parting ceremonies in dying organizations." Academy of Management journal 29(1): 5-30.

Haynie, J. M., Shepherd, D. A., \& McMullen, J. S. (2009). An opportunity for me? the role of resources in opportunity evaluation decisions. Journal of Management Studies, 46(3), 337-361.

He, X., K. D. Brouthers and I. Filatotchev (2018). "Market orientation and export performance: The moderation of channel and institutional distance." International Marketing Review 35(2): 258-279.

He, C. X., \& Karami, M. (2016). International opportunity development of internationalizing SMEs from emerging economies. (pp. 203-233). In - Devinney, Timothy M., et al. Global Entrepreneurship: Past, Present \& Future. Bingley, Emerald Group Publishing Limited

Hewerdine, L. J., Rumyantseva, M., \& Welch, C. (2014)). "Resource scavenging." International Marketing Review 31(3): 237-258.

Hitt, M. A., D. Ahlstrom, M. T. Dacin, E. Levitas and L. Svobodina (2004). "The institutional effects on strategic alliance partner selection in transition economies: China vs. Russia." Organization science 15(2): 173-185.

Hitt, M. A., M. T. Dacin, E. Levitas, J.-L. Arregle and A. Borza (2000). "Partner selection in emerging and developed market contexts: Resource-based and organizational learning perspectives." Academy of Management journal 43(3): 449-467.

Hitt, M. A., V. Franklin and H. Zhu (2006). "Culture, institutions and international strategy." Journal of International Management 12(2): 222-234.

Hitt, M. A., H. Li and W. J. Worthington (2005). "Emerging markets as learning laboratories: Learning behaviors of local firms and foreign entrants in different institutional contexts." Management and Organization Review 1(3): 353-380.

Hoskisson, R. E., H. Kim, R. E. White and L. Tihanyi (2004). A framework for understanding international diversification by business groups from emerging 
economies. "Theories of the Multinational Enterprise: Diversity, Complexity and Relevance", Emerald Group Publishing Limited: 137-163.

Hoskisson, R. E., M. Wright, I. Filatotchev and M. W. Peng (2013). "Emerging multinationals from mid-range economies: The influence of institutions and factor markets." Journal of Management Studies 50(7): 1295-1321.

Huang, S., G. Ye, J. Zhou and T. Jin (2017). "Institutional contexts, institutional capability and accelerated internationalization of entrepreneurial firms from emerging economies." Nankai Business Review International 8(2): 231-262.

Hymer, S. H. (1976). The international operations of national firms: A study of foreign direct investment, Cambridge, Ma: Mit Press.

Ibeh, K., J. Wilson and A. Chizema (2012). "The internationalization of African firms 1995-2011: Review and implications." Thunderbird International Business Review 54(4): 411-427.

Ireland, R. D., M. A. Hitt and D. G. Sirmon (2003). "A model of strategic entrepreneurship: The construct and its dimensions." Journal of management 29(6): 963-989.

Jafari Sadeghi, V., Nkongolo-Bakenda, J., Anderson, R. B., \& Dana, L. (2019). An institution-based view of international entrepreneurship: A comparison of context-based and universal determinants in developing and economically advanced countries. International Business Review, 28(6).

Ji, J., E. Plakoyiannaki, P. Dimitratos and S. Chen (2019). "The qualitative case research in international entrepreneurship: a state of the art and analysis." International Marketing Review 36(1): 164-187.

Jarzabkowski, P. (2005). Strategy as practice: An activity-based approach. London;Thousand Oaks;: Sage.

Joardar, A. and Wu, S. (2017). Liabilities and benefits: Examining the two sides of the foreignness coin from entrepreneurial perspective, International Business Review, 26(6), pp.1157-1167.

Johanson, J. and L.-G. Mattsson (2015). Internationalisation in industrial systems-a network approach. Knowledge, networks and power, Springer: 111-132.

Johnson, A. (2005). European welfare states and supranational governance of social policy. European Welfare States and Supranational Governance of Social Policy, Springer: 1-27.

Johnson, G., Melin, L., \& Whittington, R. (2003). Micro strategy and strategizing: Towards an activity-based view. Journal of Management Studies, 40(1), 3-22.

Jones, M. V., N. Coviello and Y. K. Tang (2011). "International entrepreneurship research (1989-2009): a domain ontology and thematic analysis." Journal of business venturing 26(6): 632-659.

Ketkar, S., \& Acs, Z. J. (2013). Where angels fear to tread: Internationalization of emerging country SMEs. Journal of International Entrepreneurship, 11(3), 201219. 
Khanna, T. and K. Palepu (1997). "Why focused strategies may be wrong for emerging markets." Harvard business review 75(4): 41-43.

Khanna, T., K. G. Palepu and J. Sinha (2005). "Strategies that fit emerging markets." Harvard business review 83(6): 4-19.

Kiggundu, M. N. (2002). "Entrepreneurs and entrepreneurship in Africa: What is known and what needs to be done." Journal of developmental entrepreneurship 7(3): 239.

Kiss, A. N. and W. M. Danis (2008). "Country institutional context, social networks, and new venture internationalization speed." European Management Journal 26(6): 388-399.

Kiss, A. N. and W. M. Danis (2010). "Social networks and speed of new venture internationalization during institutional transition: A conceptual model." Journal of International Entrepreneurship 8(3): 273-287.

Kiss, A. N., W. M. Danis and S. T. Cavusgilooy (2012). "International entrepreneurship research in emerging economies: A critical review and research agenda." Journal of Business Venturing 27(2): 266-290.

Knight, G. A. (2001). "Entrepreneurship and strategy in the international SME." Journal of international management 7(3): 155-171.

Kolvereid, L. and E. Isaksen (2006). "New business start-up and subsequent entry into selfemployment." Journal of Business Venturing 21: 866-885.

Kontinen, T. and A. Ojala (2011). "Network ties in the international opportunity recognition of family SMEs." International Business Review 20(4): 440-453.

Kostova, T. (1999) 'Transnational Transfer of Strategic Organizational Practices: A Contextual Perspective', Best Paper Proceedings of the Academy of Management Review 24: 308-24.

Kostova, T. and S. Zaheer (1999). "Organizational legitimacy under conditions of complexity: The case of the multinational enterprise." Academy of Management review 24(1): 64-81.

Kraemer, T. D. \& Venkataraman, S. (1997). Extraordinary feats of entrepreneurial enterprise: Strategies for rapid, sustained growth. In S. Birley \& I. C. MacMillan (Eds.), Entrepreneurship in a Global Context (pp. 82-107). London: Routledge.

Kuchař, P. (2016). "Entrepreneurship and institutional change." Journal of Evolutionary Economics 26(2): 349-379.

Kuivalainen, O., S. Sundqvist, S. Saarenketo and R. McNaughton (2012). "Internationalization patterns of small and medium-sized enterprises." International Marketing Review 29(5): 448-465.

Kujala, I. and J.-Å. Törnroos (2018). "Internationalizing through networks from emerging to developed markets with a case study from Ghana to the USA." Industrial Marketing Management 69: 98-109. 
Lamotte, O., \& Colovic, A. (2015). Early internationalization of new ventures from emerging countries: The case of transition economies. Management, 18(1), 8-30.

Langley, A., C. Smallman, H. Tsoukas and A. H. Van de Ven (2013). "Process studies of change in organization and management: Unveiling temporality, activity, and flow." Academy of management journal 56(1): 1-13.

Langseth, H., M. O'Dwyer and C. Arpa (2016). "Forces influencing the speed of internationalisation: An exploratory Norwegian and Irish study." Journal of Small Business and Enterprise Development 23(1): 122-148.

Le, N. T., S. Venkatesh and T. V. Nguyen (2006). "Getting bank financing: A study of Vietnamese private firms." Asia Pacific Journal of Management 23(2): 209-227.

$\mathrm{Li}, \mathrm{J}$. (2013). The internationalization of entrepreneurial firms from emerging economies: The roles of institutional transitions and market opportunities. Journal of International Entrepreneurship, 11(2), pp.158-171.

Li, J., Y. Li and D. Shapiro (2012). "Knowledge seeking and outward FDI of emerging market firms: The moderating effect of inward FDI." Global Strategy Journal 2(4): 277-295.

Li, J. J. and K. Z. Zhou (2010). "How foreign firms achieve competitive advantage in the Chinese emerging economy: Managerial ties and market orientation." Journal of Business Research 63(8): 856-862.

Li, Q. and P. Deng (2017). "From international new ventures to MNCs: Crossing the chasm effect on internationalization paths." Journal of Business Research 70: 92100.

Liou, R., \& Rao-Nicholson, R. (2017). Out of africa: The role of institutional distance and host-home colonial tie in south african firms' post-acquisition performance in developed economies. International Business Review, 26(6): 1184-1195.

Lim, D. S., C. H. Oh and D. De Clercq (2016). "Engagement in entrepreneurship in emerging economies: Interactive effects of individual-level factors and institutional conditions." International Business Review 25(4): 933-945.

Lindstrand, A., \& Hånell, S. M. (2017). International and market-specific social capital effects on international opportunity exploitation in the internationalization process. Journal of World Business : JWB, 52(5), 653-663.

Locke, K. D. (2000). Grounded theory in management research, Sage.

London, T. and S. L. Hart (2004). "Reinventing strategies for emerging markets: beyond the transnational model." Journal of international business studies 35(5): 350-370.

Lorentz, H. and P. N. Ghauri (2010). "Demand supply network opportunity development processes in emerging markets: Positioning for strategy realization in Russia." Industrial Marketing Management 39(2): 240-251.

Lu, Y., L. Zhou, G. Bruton and W. Li (2010). "Capabilities as a mediator linking resources and the international performance of entrepreneurial firms in an emerging economy." Journal of International Business Studies 41(3): 419-436. 
Lundberg, H., \& Rehnfors, A. (2018). Transnational entrepreneurship: Opportunity identification and venture creation. Journal of International Entrepreneurship, $16(2), 150-175$.

Luo, Y., \& Tung, R. L. (2007). International expansion of emerging market enterprises: A springboard perspective. Journal of International Business Studies, 38(4), 481-498.

Luo, Y., Xue, Q., \& Han, B. (2010). How emerging market governments promote outward FDI: Experience from china. Journal of World Business : JWB, 45(1), 68-79.

Ma, X., Z. Ding and L. Yuan (2016). Subnational institutions, political capital, and the internationalization of entrepreneurial firms in emerging economies. Journal of World Business 51(5): 843-854.

Mainela, T., V. Puhakka and P. Servais (2014). "The concept of international opportunity in international entrepreneurship: a review and a research agenda." International journal of management reviews 16(1): 105-129.

Marano, V., P. Tashman and T. Kostova (2017). "Escaping the iron cage: Liabilities of origin and CSR reporting of emerging market multinational enterprises." Journal of International Business Studies 48(3): 386-408.

Maskus, K. E. (2002). "Regulatory standards in the WTO: Comparing intellectual property rights with competition policy, environmental protection, and core labor standards." World Trade Review 1(2): 135-152.

Masiello, B., \& Izzo, F. (2019). Interpersonal social networks and internationalization of traditional SMEs. Journal of Small Business Management, 57(sup2), 658-691.

McCline, R., S. Bhat and P. Baj (2000). "Opportunity recognition: An exploratory investigation of a component of the entrepreneurial process in the context of the health care industry." Entrepreneurship Theory \& Practice 25: 81-94.

McDougall, P. P., Shane, S., \& Oviatt, B. M. (1994). Explaining the formation of international new ventures: The limits of theories from international business research. Journal of Business Venturing, 9(6): 469-487.

Meyer, K. E. and M. W. Peng (2016). "Theoretical foundations of emerging economy business research." Journal of International Business Studies 47(1): 3-22.

Miao, C., Rutherford, M. W., \& Pollack, J. M. (2017). An exploratory meta-analysis of the nomological network of bootstrapping in SMEs. Journal of Business Venturing Insights, 8, 1-8.

Miles, M. B., A. M. Huberman, M. A. Huberman and M. Huberman (1994). Qualitative data analysis: An expanded sourcebook, sage.

Mingo, S., M. Junkunc and F. Morales (2018). "The interplay between home and host country institutions in an emerging market context: Private equity in Latin America." Journal of World Business 53(5): 653-667.

Miocevic, D. and R. E. Morgan (2018). "Operational capabilities and entrepreneurial opportunities in emerging market firms: Explaining exporting SME growth." International Marketing Review 35(2): 320-341. 
Muralidharan, E., \& Pathak, S. (2017). Informal institutions and international entrepreneurship. International Business Review, 26(2), 288-302.

Musteen, M., Francis, J., \& Datta, D. K. (2010). The influence of international networks on internationalization speed and performance: A study of czech SMEs. Journal of World Business : JWB, 45(3), 197-205.

Nikolaev, B. N., Boudreaux, C. J., \& Palich, L. (2018). Cross-country determinants of earlystage necessity and opportunity-motivated entrepreneurship: Accounting for model uncertainty. Journal of Small Business Management, 56(S1), 243-280.

North, D. C. (1990). Institutions, Institutional Change, and Economic Performance, Cambridge University Press.

North, D. C. (1990). "A transaction cost theory of politics." Journal of theoretical politics 2(4): 355-367.

North, D. C. (1991). "Institutions." Journal of economic perspectives 5(1): 97-112.

North, D. C. (1994). "Economic performance through time." The American economic review: 359-368.

Oliver, C. (1991) Strategic responses to institutional processes. The Academy of Management Review, 16(1), 145-179.

Oviatt, B. M. and P. P. McDougall (2005). "Defining international entrepreneurship and modeling the speed of internationalization." Entrepreneurship theory and practice 29(5): 537-553.

Owens, M., E. Ramsey and S. Loane (2018). "Resolving post-formation challenges in shared IJVs: The impact of shared IJV structure on inter-partner relationships." International Business Review 27(3): 584-593.

Oyedele, A. and F. Firat (2019). "Institutions, small local firms' strategies, and global alliances in sub-Saharan Africa emerging markets." International Marketing Review 37(1): 156-182.

Oyson, M. J. and D. H. Whittaker (2010). "Creativity and prospection: creating and exploiting opportunities for international entrepreneurship." Acta Tech Corveniensis 4: 125-131.

Pajunen, K. (2008). "Institutions and inflows of foreign direct investment: A fuzzy-set analysis." Journal of International Business Studies 39(4): 652-669.

Park, S. and Z.-T. Bae (2004). "New venture strategies in a developing country: Identifying a typology and examining growth patterns through case studies." Journal of Business Venturing 19(1): 81-105.

Patton, M. Q. (1990). Qualitative evaluation and research methods, SAGE Publications, inc.

Paul, J. and G. R. Benito (2018). "A review of research on outward foreign direct investment from emerging countries, including China: what do we know, how do we know and where should we be heading?" Asia Pacific Business Review 24(1): 90-115. 
Peiris, I. K., M. E. Akoorie and P. Sinha (2012). "International entrepreneurship: A critical analysis of studies in the past two decades and future directions for research." Journal of International Entrepreneurship 10(4): 279-324.

Peng, M. W. (1997). Firm Growth in Transitional Economies: Three Longitudinal Cases from China, 1989-96. Organization Studies, 18(3), 385-413.

Peng, M. W. (2003). "Institutional transitions and strategic choices." Academy of management review 28(2): 275-296.

Peng, M. W., D. Ahlstrom, S. M. Carraher and W. S. Shi (2017). "An institution-based view of global IPR History." Journal of International Business Studies 48(7): 893907.

Peng, M. W., \& Heath, P. S. (1996). The growth of the firm in planned economies in transition: Institutions, organizations, and strategic choice. The Academy of Management Review, 21(2), 492-528.

Peng, Y. (2004). "Kinship networks and entrepreneurs in China's transitional economy." American Journal of Sociology 109(5): 1045-1074.

Perry, C. (1998). Processes of a case study methodology for postgraduate research in marketing. European Journal of Marketing, 32(9/10), 785-802.

Pettigrew, A. M. (1990). "Longitudinal field research on change: Theory and practice." Organization science 1(3): 267-292.

Puffer, S. M., D. J. McCarthy and M. Boisot (2010). "Entrepreneurship in Russia and China: The impact of formal institutional voids." Entrepreneurship theory and practice 34(3): 441-467.

Radulovich, L., R. G. Javalgi and R. F. Scherer (2018). "Intangible resources influencing the international performance of professional service SMEs in an emerging market: Evidence from India." International Marketing Review 35(1): 113-135.

Santos, F. M. and K. M. Eisenhardt (2009). "Constructing markets and shaping boundaries: Entrepreneurial power in nascent fields." Academy of Management Journal 52(4): 643-671.

Sasi, V. and P. Arenius (2008). "International new ventures and social networks: advantage or liability?" European Management Journal 26(6): 400-411.

Scott, W. R. (1995) Institutions and Organizations: Theory and Research. Thousand Oaks, CA: Sage.

Sharma, R. R., G. Sraha and D. Crick (2018). "Export promotion programmes and the export performance of Ghanaian firms: the mediating role of foreign market attractiveness." International Marketing Review 35(4): 661-682.

Shepherd, D. and D. DeTienne (2001). Discovery of opportunities: Anomalies, accumulation and alertness. Frontiers of entrepreneurship research. E. Bygrave, E. Autio and C. Brush. Wellesley, MA, Babson Collect: 138-148.

Shimp, T. A., \& Sharma, S. (1987). Consumer ethnocentrism: Construction and validation of the CETSCALE. Journal of Marketing Research, 24(3), 280. 
Smallbone, D., B. Piasecki, U. Venesaar, K. Todorov and L. Labrianidis (1998). "Internationalisation and SME development in transition economies: an international comparison." Journal of Small Business and Enterprise Development 5(4): 363-375.

Smallbone, D. and F. Welter (2006). Institutional development and entrepreneurship in a transition context. Developmental Entrepreneurship: Adversity, Risk, And Isolation, Emerald Group Publishing Limited: 37-53.

Smallbone, D., F. Welter and J. Ateljevic (2014). "Entrepreneurship in emerging market economies: Contemporary issues and perspectives." International Small Business Journal 32(2): 113-116.

Stenholm, P., Z. J. Acs and R. Wuebker (2013). "Exploring country-level institutional arrangements on the rate and type of entrepreneurial activity." Journal of Business Venturing 28(1): 176-193.

Styles, C. and S. Gray (2006). "Advancing research in international entrepreneurship." International Marketing Review 23(5).

Szyliowicz, D. and T. Galvin (2010). "Applying broader strokes: Extending institutional perspectives and agendas for international entrepreneurship research." International Business Review 19(4): 317-332.

Thomas, D. E., L. Eden, M. A. Hitt and S. R. Miller (2007). "Experience of emerging market firms: The role of cognitive bias in developed market entry and survival." Management International Review 47(6): 845-867.

Torkkeli, L., O. Kuivalainen, S. Saarenketo and K. Puumalainen (2019). "Institutional environment and network competence in successful SME internationalisation." International Marketing Review 36(1): 31-55.

Turcan, R. (2013). International new venture legitimation: An exploratory study. Administrative Sciences, 3(4), 237-265.

Turner, S. F., \& Rindova, V. (2012). A balancing act: How organizations pursue consistency in routine functioning in the face of ongoing change. Organization Science (Providence, R.I.), 23(1), 24-46.

US Department of State: US Relations with Nigeria (Available at: https://www.state.gov/u-s-relations-with-nigeria/) Downloaded: 24 August 2020.

Urbano, D. and C. Alvarez (2014). "Institutional dimensions and entrepreneurial activity: an international study." Small Business Economics 42(4): 703-716.

Uzzi, B. (1996). The sources and consequences of embeddedness for the economic performance of organizations: The network effect. American Sociological Review, 61(4), 674-698.

Vahlne, J., \& Johanson, J. (2020). The Uppsala model: Networks and micro-foundations. Journal of International Business Studies, 51, 4-10.

Valdez, M. E. and J. Richardson (2013). "Institutional determinants of macro-level entrepreneurship." Entrepreneurship theory and practice 37(5): 1149-1175. 
Vasilchenko, E., \& Morrish, S. (2011). The role of entrepreneurial networks in the exploration and exploitation of internationalization opportunities by information and communication technology firms. Journal of International Marketing (East Lansing, Mich.), 19(4), 88-105.

Veciana, J. M. and D. Urbano (2008). The institutional approach to entrepreneurship research. Introduction, Springer.

Voigt, S. and H. Engerer (2002). Institutions and transformation-possible policy implications of the new institutional economics. Frontiers in economics, Springer: 127-184.

Volchek, D., A. Jantunen and S. Saarenketo (2013). "The institutional environment for international entrepreneurship in Russia: Reflections on growth decisions and performance in SMEs." Journal of International Entrepreneurship 11(4): 320-350.

Wan, W. P. (2005). "Country resource environments, firm capabilities, and corporate diversification strategies." Journal of Management Studies 42(1): 161-182.

Webb, J. W., G. M. Kistruck, R. D. Ireland and J. Ketchen, David J (2010). "The entrepreneurship process in base of the pyramid markets: The case of multinational enterprise/nongovernment organization alliances." Entrepreneurship theory and practice 34(3): 555-581.

Welch, C., N. Nummela and P. Liesch (2016). The internationalization process model revisited: An agenda for future research, Springer.

Williams, N. and T. Vorley (2015). "Institutional asymmetry: How formal and informal institutions affect entrepreneurship in Bulgaria." International Small Business Journal 33(8): 840-861.

Williamson, O. E. (1991). "Comparative economic organization: The analysis of discrete structural alternatives." Administrative science quarterly: 269-296.

Witt, M. A. and A. Y. Lewin (2007). "Outward foreign direct investment as escape response to home country institutional constraints." Journal of International business studies 38(4): 579-594.

Wright, M., I. Filatotchev, R. E. Hoskisson and M. W. Peng (2005). "Strategy research in emerging economies: Challenging the conventional wisdom." Journal of management studies 42(1), 1-33.

Wu, J. (2013). Diverse Institutional Environments and Product Innovation of Emerging Market Firms. Management International Review, 53(1), 39-59.

$\mathrm{Wu}$, J. and Chen, X. (2014). Home country institutional environments and foreign expansion of emerging market firms. International Business Review, 23(5), 862872.

Wu, B. and P. Deng (2020). "Internationalization of SMEs from emerging markets: An institutional escape perspective." Journal of Business Research 108: 337-350..

$\mathrm{Xu}$, D. and O. Shenkar (2002). "Note: Institutional distance and the multinational enterprise." Academy of Management review 27(4): 608-618. 
Yamakawa, Y., M. W. Peng and D. L. Deeds (2008). "What Drives New Ventures to Internationalize from Emerging to Developed Economies?" Entrepreneurship: Theory \& Practice 32(1): 59-82.

Yang, M. M., T. Li and Y. Wang (2020). "What explains the degree of internationalization of early-stage entrepreneurial firms? A multilevel study on the joint effects of entrepreneurial self-efficacy, opportunity-motivated entrepreneurship, and home-country institutions." Journal of World Business 55(6): 101114.

Yeung, H. W.-C. (2002). "Entrepreneurship in international business: An institutional perspective." Asia Pacific Journal of Management 19(1): 29-61.

Yin, R. K. (1994). Case study research: Design and methods (2nd ed.). Thousand Oaks, Calif;London;: Sage.

Zaefarian, R., Eng, T., \& Tasavori, M. (2016). An exploratory study of international opportunity identification among family firms. International Business Review, 25(1): 333-345.

Zahra, S. A., J. S. Korri and J. Yu (2005). "Cognition and international entrepreneurship: implications for research on international opportunity recognition and exploitation." International business review 14(2): 129-146.

Zahra, S. A., Wright, M., \& Abdelgawad, S. G. (2014). Contextualization and the advancement of entrepreneurship research. International Small Business Journal, 32(5), 479-500. International business review 14(2): 129-146.

Zenger, T. R., S. G. Lazzarini and L. Poppo (2000). Informal and formal organization in new institutional economics. The new institutionalism in strategic management, Emerald Group Publishing Limited: 277-305.

Zhu, H., M. A. Hitt and L. Tihanyi (2006). "The Internationalization of SMES in Emerging Economies: Institional Embeddedness and Absorptive Capacities." Journal of Small Business Strategy 17(2): 1-26.

Zwane, B. K., \& Nyide, C. J. (2017). SMME attitudes towards financial bootstrapping: A perspective from a developing economy. Business and Economic Horizons, 13(3): 347-356. 


\section{Appendix A: Interview Prompt Sheet}

\section{Entrepreneur interview protocol}

General Aspects

Background of the firm

The process

- Explain to me, what led you to start this business in the US?

- What are the things you did to make the business feasible?

- How did you finance operations? Who helped you?

Institutional factors

- You have explained several activities of your firm, how does the working environment of both Nigeria and the US affect these activities.

- What are the challenges you encountered in Nigeria and what are the challenges you encountered in the US? 


\section{Table 1: Characteristics and basic profile of the cases}

\begin{tabular}{|c|c|c|c|c|}
\hline Case studies & Case $\mathrm{A}$ & Case B & Case $\mathrm{C}$ & Case D \\
\hline Entrepreneur profile & $\begin{array}{l}\text { Co-owned and managed by husband } \\
\text { and wife, } 60 \text { and } 53 \text { years old } \\
\text { respectively, US (New Jersey) }\end{array}$ & Male, 62 years old, US (New York) & Female, 48 years old, US (Austin, Texas) & $\begin{array}{l}\text { Co-owned and managed by husband and } \\
\text { wife, } 56 \text { and } 50 \text { years old, US (Houston, } \\
\text { Texas) }\end{array}$ \\
\hline $\begin{array}{l}\text { Entrepreneur } \\
\text { background and } \\
\text { experience prior to } \\
\text { start up }\end{array}$ & $\begin{array}{l}\text { Entrepreneurs have reasonably high } \\
\text { levels of education and professional } \\
\text { preparation. Husband worked as a } \\
\text { manager of a multinational company } \\
\text { for } 20 \text { years. He has also trained in } \\
\text { marketing and business strategy at the } \\
\text { Lagos School of Business. Wife on the } \\
\text { other hand, trained in food processing, } \\
\text { management, and marketing at the } \\
\text { Mississippi State University in the US. }\end{array}$ & $\begin{array}{l}\text { Entrepreneur has reasonably low level of } \\
\text { formal education but extensive } \\
\text { experience and professional preparation. } \\
\text { He was engaged in promoting African } \\
\text { music and arts through an in-house } \\
\text { magazine publication and sponsoring } \\
\text { stage cultural events and festivals within } \\
\text { Nigeria and internationally for } 20 \text { years }\end{array}$ & $\begin{array}{l}\text { Entrepreneur has above-average level of } \\
\text { formal education but minimal experience } \\
\text { and professional preparation. A degree in } \\
\text { Theatre arts at the University of Port } \\
\text { Harcourt. } 3 \text { years experience of filmmaking } \\
\text { in home market (Nigeria) before venturing } \\
\text { into the US foreign market. }\end{array}$ & $\begin{array}{l}\text { Entrepreneurs have low levels of formal } \\
\text { education with extensive experience and } \\
\text { professional preparations. The wife } \\
\text { received training through a USAID } \\
\text { supported program in food production } \\
\text { techniques, packaging, and labeling. } 20 \\
\text { years experience of US leather importation } \\
\text { to Nigeria. }\end{array}$ \\
\hline $\begin{array}{l}\text { Reasons for entry } \\
\text { into US }\end{array}$ & $\begin{array}{l}\text { The entrepreneurs were seeking } \\
\text { opportunities to expand as home } \\
\text { market had become saturated }\end{array}$ & $\begin{array}{l}\text { The opportunity to tap into a lucrative US } \\
\text { niche market for Nigerian films }\end{array}$ & $\begin{array}{l}\text { The entrepreneur's passion for } \\
\text { international filmmaking }\end{array}$ & $\begin{array}{l}\text { Need for survival after a government policy } \\
\text { proclamation banned finished leather } \\
\text { imports, which effectively pushed the } \\
\text { entrepreneurs out of business. }\end{array}$ \\
\hline $\begin{array}{l}\text { Business activity, } \\
\text { year of est. and } \\
\text { location, annual } \\
\text { turnover, no. of } \\
\text { employees }\end{array}$ & $\begin{array}{l}\text { Processed food exports, 2007, Lagos, } \\
\text { New Jersey, } \\
\text { N410,000,000 }(\$ 1,170,000) \\
121 \text { employees }\end{array}$ & $\begin{array}{l}\text { Filmmaking, 1997, Harlem, New York, } \\
\text { N295,000,000 }(\$ 842,000) \\
82 \text { employees }\end{array}$ & $\begin{array}{l}\text { Filmmaking, 2005, Enugu, Austin } \\
\text { N240,000,000 }(\$ 685,000) \\
48 \text { employees }\end{array}$ & $\begin{array}{l}\text { Processed food exports, 1993, Lagos, } \\
\text { Houston } \\
\text { N175,000,000 }(\$ 500,000) \\
65 \text { employees }\end{array}$ \\
\hline $\begin{array}{l}\text { Business history } \\
\text { (antecedents and } \\
\text { key characteristics) }\end{array}$ & $\begin{array}{l}\text { The entrepreneurs began as a food } \\
\text { processing enterprise in Nigeria } \\
\text { achieving remarkable success over the } \\
\text { years. However, increasing intense } \\
\text { local competition would significantly } \\
\text { dampen their market share and stifle } \\
\text { growth prospects. This prompted the } \\
\text { need to expand and enter into the US } \\
\text { foreign market. }\end{array}$ & $\begin{array}{l}\text { From his experience of } 30 \text { years living in } \\
\text { the US, the entrepreneur saw a lucrative } \\
\text { market for African-themed products in } \\
\text { the US. He began pursuing this } \\
\text { opportunity through publishing, } \\
\text { sponsorship of cultural events and } \\
\text { festivals. These market exploits brought } \\
\text { commercial success, which encouraged } \\
\text { the entrepreneur to expand and seek } \\
\text { new markets in film production. }\end{array}$ & $\begin{array}{l}\text { Owing to a lifelong ambition to become an } \\
\text { international filmmaker, the entrepreneur } \\
\text { started by setting her filmmaking company } \\
\text { in Enugu immediately after her college } \\
\text { education in 2005. Initially, a shortage in } \\
\text { finances frustrated the entrepreneur's } \\
\text { international ambitions, and limited her } \\
\text { choices. However, in 2008, a US } \\
\text { government incentives program that } \\
\text { supports filmmakers prompted the }\end{array}$ & $\begin{array}{l}\text { The entrepreneurs previously imported US } \\
\text { leather products to Nigeria. In 1990, } \\
\text { however, Nigerian government banned the } \\
\text { importation of finished leather products. } \\
\text { This situation pushed the entrepreneurs } \\
\text { out of business and forced them to } \\
\text { consider alternative business } \\
\text { engagements. Hence, leveraging their } \\
\text { existing knowledge of the US market, the } \\
\text { entrepreneurs decided to enter food } \\
\text { exports to the US. }\end{array}$ \\
\hline
\end{tabular}




\begin{tabular}{|c|c|c|c|c|}
\hline & & & $\begin{array}{l}\text { entrepreneur to take the initiative and } \\
\text { expand operations to the US. }\end{array}$ & \\
\hline $\begin{array}{l}\text { In case } \\
\text { corroborating } \\
\text { interviewees (in } \\
\text { addition to } \\
\text { entrepreneurs) }\end{array}$ & $\begin{array}{ll} & \text { Director Operations } \\
\text { - } & \text { Production Manager }\end{array}$ & $\begin{array}{ll}- & \text { Executive Director } \\
\text { - } & \text { Operations Manager } \\
\text { - } & \text { Company Editor }\end{array}$ & $\begin{array}{ll}- & \text { Managing Director } \\
\text { - } & \text { Exports Director } \\
\text { - } & \text { Sales Manager }\end{array}$ & $\begin{array}{ll}- & \text { Sales Manager } \\
\text { - } & \text { Production Manager }\end{array}$ \\
\hline
\end{tabular}

1

18

19

20

21

22

23

24

26

27

28

29

30

31

32

33

34

35

36

37

38

39

40

41

42 
Table 2: Type of data and use

\begin{tabular}{|c|c|c|}
\hline Source & Type of data & Use in the analysis \\
\hline \multirow[t]{2}{*}{$\begin{array}{l}\text { Firm } \\
\text { archive }\end{array}$} & $\begin{array}{l}\text { Pre-interview collection: Firm websites (4); Media } \\
\text { information (ca. } 22 \text { pages); Key management CVs (16); } \\
\text { Financial reports (4) } \\
\text { In-interview collection: Marketing literature (ca } 16 \\
\text { pages); New market entry plans (14); Notes recording } \\
\text { details of visual aids (6 pages); Meeting minutes and } \\
\text { notes (4 pages); shipment documents (ca } 4 \text { pages) }\end{array}$ & $\begin{array}{c}\text { Gather information to support interpretation } \\
\text { and triangulation of verbal explanations by } \\
\text { interviewees }\end{array}$ \\
\hline & $\begin{array}{l}\text { Post-interview collection: Interviewee field notes (ca } \\
\qquad 23 \text { pages) }\end{array}$ & $\begin{array}{l}\text { Recording of nonverbal signals, atmospheric } \\
\text { influences and observed processes. } \\
\text { Interpretation of firm and its environment. }\end{array}$ \\
\hline \multirow[t]{2}{*}{$\begin{array}{l}\text { Semi } \\
\text { structured } \\
\text { interviews }\end{array}$} & $\begin{array}{l}\text { Pilot Study: Summer } 2012 \text { interviews with } 4 \\
\text { entrepreneurs involving founders of exporting firms in } \\
\text { Nigeria. All recorded and transcribed for a total of } 68 \\
\text { pages }\end{array}$ & $\begin{array}{l}\text { Gather data on firm internationalisation process } \\
\text { to test and refine interview prompt sheet. Seek } \\
\text { guidance and introductions into suitable cases. }\end{array}$ \\
\hline & $\begin{array}{c}\text { Main Stage: Summer 2013- Spring 2014. } 16 \text { interviews } \\
\text { across four cases involving } 6 \text { owner managers; } 4 \\
\text { directors, } 6 \text { middle management level all with direct } \\
\text { international experience. All recorded and transcribed } \\
\text { for a total of ca } 140 \text { pages. }\end{array}$ & $\begin{array}{l}\text { Gather rich multi voice and triangulated data } \\
\text { exploring how institutional factors influence } \\
\text { international opportunities. }\end{array}$ \\
\hline \multirow[t]{2}{*}{$\begin{array}{l}\text { Other } \\
\text { archival } \\
\text { sources }\end{array}$} & $\begin{array}{c}\text { Pre-interview collection: Industry agency websites (18 } \\
\text { websites); Competitor websites and media articles (ca } \\
14 \text { pages); OECD/World Bank ( } 12 \text { pages) other } \\
\text { industry reports ( } 36 \text { pages); Key economic data on } \\
\text { select markets ( } 21 \text { pages). }\end{array}$ & $\begin{array}{l}\text { Contribution to creating report to assess the } \\
\text { viability of Nigerian SMEs as a research setting } \\
\text { for exploring IE process. Identify dominant } \\
\text { logic of the sector. }\end{array}$ \\
\hline & $\begin{array}{c}\text { Post-interview collection: Ongoing data collection } \\
\text { from public sources (ca } 12 \text { pages); company documents } \\
\text { such as memos (16 pages); } \\
\text { External informant experts: } 12 \text { interviews involving } \\
6 \text { institutional informants, } 3 \text { academics and } 3 \\
\text { consultants. All recorded and transcribed for a total of } \\
\text { ca } 100 \text { pages. }\end{array}$ & $\begin{array}{l}\text { Triangulate facts and observations. Enhance } \\
\text { validity of insights, contextualize observed and } \\
\text { verbal processes. Develop insights on formal } \\
\text { and informal characteristics of institutional } \\
\text { environments in both Nigeria and the US. }\end{array}$ \\
\hline
\end{tabular}


Table 3: Theoretical Underpinning of the Data

\begin{tabular}{|c|c|c|}
\hline $\begin{array}{c}\text { Stage of IE } \\
\text { Activity Process }\end{array}$ & Home institutional influence & Host institutional influence \\
\hline $\begin{array}{l}\text { Opportunity } \\
\text { Recognition }\end{array}$ & $\begin{array}{l}\text { Intent to escape home formal } \\
\text { institutions }\end{array}$ & Engaging social ties \\
\hline $\begin{array}{l}\text { Opportunity } \\
\text { Development }\end{array}$ & $\begin{array}{l}\text { Constraints to escape home } \\
\text { formal institutions }\end{array}$ & $\begin{array}{c}\text { Engaging formal institutions } \\
- \text { country of origin } \\
\text { discrimination } \\
\text { Engaging social ties } \\
\text { Bootstrapping }\end{array}$ \\
\hline $\begin{array}{l}\text { Opportunity } \\
\text { Exploitation }\end{array}$ & $\begin{array}{l}\text { Adverse impact of home formal } \\
\text { institutions }\end{array}$ & $\begin{array}{c}\text { Engaging formal institutions } \\
\text { - enabling regulatory and } \\
\text { government support }\end{array}$ \\
\hline
\end{tabular}

